Digitalizacja archiwalnych numerów czasopisma naukowego Analecta Cracoviensia 1-24 (1969-1992) i ich publikacja w otwartym dostępie - zadanie finansowane w ramach umowy 672/P-DUN/2017 ze środków Ministra Nauki i Szkolnictwa Wyższego przeznaczonych na działalność upowszechniającą naukę

ANALECT A CRACOVIENSIA

$4(1972$ 267-314

\title{
REFORMA KANONICZNEGO PROCESU MAŁŻENSSKIEGO WEDŁUG MOTU PROPRIO PAP. PAWŁA VI „CAUSAS MATRIMONIALES“
}

WSTEP

Wcześniej, niż się tego spodziewano, pap. Paweł VI dokonał nowego kroku w kierunku reformy procesu w sprawach małżeńskich.

Po wprowadzeniu w życie z dniem 1 lipca 1970 r. eksperymentalnych Norm postępowania $w$ sprawach matżenskich w Stanach Zjednoczonych Ameryki Północnej, wydanych dla tamtejszych trybunałów kościelnych na okres trzech lat ${ }^{1}$, wydawało się, że nie wcześniej, jak po upływie tego czasu, można się spodziewać rewizji ogólnokościelnych przepisów obowiązujących przy orzekaniu nieważności małżeństwa.

Stało się jednak inaczej.

Przyczyn tego kroku można się doszukać w niecierpliwości niektórych episkopatów narodowych, które natychmiast po uzyskaniu zmian i ułatwień w prowadzeniu spraw małżeńskich przez trybunały amerykańskie zwróciły się do Stolicy Apostolskiej z prośbą o analogiczne przywileje dla siebie. Już 31 sierpnia 1970 r. Normy amerykańskie zostały bez żadnych zmian przyznane diecezjom australijskim ${ }^{2}$, 10 listopada $1970 \mathrm{r}$. Sygnatura Apostolska wyraziła zgodę na propozycje Konferencji Episkopatu Belgii, zawierające ważne zmiany w procedurze spraw małżeńskich ${ }^{3}$, a 2 stycznia 1971 r. podobne zmiany wprowadzono w trybunałach ko-

1 Normy te nie ukazały się w Acta Apostolicae Sedis. Można je znaleźć w art. Mc Manus F., Procedural norms for Matrimonial Cases, W: The Jurist 30 (1970) $363-368$.

2 L'Osservatore Romano z dn. 14-15 czerwca 1971 r., s. 1.

3 Gordon I., Documenta recentiora circa rem matrimonialem et processualem, Romae 1971 , s. 45-46. Zmiany te dotyczą zarówno procesów przy orzekaniu nieważności małżeństwa, jak też spraw związanych $\mathrm{z}$ dyspensą od małżeństwa niedopełnionego. 
ścielnych Anglii i Walii, na prośbę tamtejszych Konferencji Episkopatu 4. Dalsze prośby, zwłaszcza z regionów posługujących się językiem angielskim, poczęły licznie napływać do Rzymu.

W tej sytuacji istniały dwa możliwe rozwiązania: albo poszerzać zasięg eksperymentalnych norm typu amerykańskiego czy belgijskiego, co wkrótce mogłoby doprowadzić do niepożądanej sytuacji powstania wielu odrębnych systemów procesowych, albo zastanowić się nad ogólnokościelnym, jednorodnym ustawodawstwem, które zarówno tym, którzy o to proszą, jak i tym, którzy o to nie dbają, otworzyłoby drogę do przyspieszenia zalegających $\mathrm{w}$ trybunałach kościelnych spraw małżeńskich, gdyż problem przyspieszenia procesu wydawał się najbardziej palącym ${ }^{5}$.

Wybrano drugie rozwiązanie, za czym przemawiała tak konieczność jednolitego ustawodawstwa procesowego w całym Kościele, jak i zaawansowane już prace nad jego projektem. Powołana w tym celu specjalna grupa robocza przy Papieskiej Komisji Rewizji Kodeksu Prawa Kanonicznego opracowała nowe przepisy, poddając je — jak to jest obecnie w zwyczaju - kontroli różnych zainteresowanych dykasteriów Kurii Rzymskiej, a w końcu Ojcu Świętemu do zatwierdzenia ${ }^{6}$.

Dokument zawierający nowe zasady procesu małżeńskiego dla Kościoła powszechnego został wydany przez pap. Pawła VI motu proprio w dniu 28 marca 1971 r. i zaczyna się od słów Causas matrimoniales. Ukazal się on jednak dopiero w numerze dziennika watykańskiego L'Osservatore Romano z dnia 11-12 czerwca 1971 r., a w Acta Apostolicae Sedis dnia 30 czerwca 1971 r. ${ }^{7}$.

Nowy akt ustawodawczy został zilustrowany na specjalnej konferencji, w sali pracowej Watykanu, przez sekretarza Papieskiej Komisji Rewizji Kodeksu Prawa Kanonicznego, o. prof. Rajmunda B i d a g o r a, który przy okazji odpowiedział na szereg pytań dotyczących dokumentu, postawionych $\mathrm{mu}$ przez dziennikarzy ${ }^{8}$.

Dokument papieski składa się ze wstępu, w którym określone zostały założenia dokonanej reformy, oraz z pięciu rozdziałów poświęconych kolejno: właściwości trybunałów kościelnych w sprawach małżeńskich, ich ustanawianiu, sprawie apelacji, zasadom postępowania w wypadkach specjalnych i zarządzeniom przejściowym. Pierwsze cztery rozdziały dzielą się na 13 norm, które z kolei dzielą się na paragrafy, ostatni zaś rozdział ma osobny podział na trzy numery.

4 Tamże, s. $46-48$.

5 Gordon I., De nimia processuum matrimonialium duratione, W: Periodica de re morali canonica liturgica 58 (1969) 646-668 i 702-711. Autor poddaje szczegółowej analizie sytuację w sądownictwie kościelnym i wysuwa na pierwszy plan potrzebę przyspieszenia procesów małżeńskich.

6 Communicationes 1 (1971) 101-106.

7 AAS 63 (1971) 441-446.

s Communicationes 1 (1971) 95-101. Również L'Osservatore Romano $z$ dn. 13 czerwca 1971 r., s. 2. 


\section{ZAEOŻENIA REFORMY}

Wstęp motu proprio Causas matrimoniales podkreśla mocno duszpasterski charakter pracy sędziów kościelnych, boleje nad wzrostem liczby spraw małżeńskich, co — zdaniem papieża — ,jest szczególnym znakiem zmniejszonego poczucia rzeczy świętej związanej z prawem natury, na którym jakby na fundamencie opiera się chrześcijańska rodzina, jest przejawem niespokojnego i zmąconego życia dzisiejszego, oznaką niepewnych warunków socjalnych i ekonomicznych, w jakich się ona znajduje, a zatem niebezpieczeństwa, które może zagrozić trwałości, sile i szczęściu instytucji rodzinnej" 9 .

Kościół wprawdzie żywi nadzieję, „że wysiłek ostatniego Soboru powszechnego, włożony w naświetlenie i rozwój duchowego dobra, jakim jest małżeństwo, oraz w duszpasterską troskę o nie, wyda swój owoc także w stosunku do trwałości związku małżeńskiego, jednakże pragnie również, przez wydanie odpowiednich przepisów, zatroszczyć się o to, by zbytnie przedłużanie się procesów małżeńskich nie stawiało w gorszej sytuacji duchowej wielu jego wiernych".

Rolę trybunałów kościelnych i przepisów procesowych widzi więc papież we właściwych proporcjach. Same z siebie nie są one w stanie ani zmienić nastawienia współczesnego świata do instytucji rodziny i małżeństwa, ani nie mogą zmniejszyć ilości spraw małżeńskich, które wierni przedstawiają władzy kościelnej do rozstrzygnięcia. Tę pracę będzie się starał spełnić Kościół przez swoją naukę i otoczenie troskliwą opieką duszpasterską podstawowych instytucji życia społecznego. Przepisy proceduralne w sprawach o orzeczenie nieważności małżeństwa nie były przyczyną wzrostu ilości spraw małżeńskich w sądach kościelnych, stanowiły natomiast niejednokrotnie przeszkodę w szybszym ich załatwianiu. Wystarczy przejrzeć zbiór wyroków rotalnych na przestrzeni ostatnich pięćdziesięciu lat, by stwierdzić, że ostateczne decyzje, w niektórych sprawach małżeńskich, zapadały dopiero po upływie 12, 15, czy nawet 20 lat od momentu wniesienia sprawy do trybunału kościelnego pierwszej instancji, a do rzadkości należą procesy, które na szczeblu Roty Rzymskiej kończą się wcześniej, niż przed upływem pięciu lat. Jak wielkie szkody duchowe i materialne pociąga za sobą taka zwłoka w wymiarze sprawiedliwości, nie trzeba chyba tłumaczyć ${ }^{10}$.

Stąd też pap. Paweł VI, nie czekając na pełniejszą reformę procesu małżeńskiego, którą przygotowuje Papieska Komisja Rewizji Kodeksu Prawa Kanonicznego, uznał za stosowne już obecnie ,wydanie niektó-

9 AAS 63 (1971) 441-442. Papież cytuje tu fragment swego przemówienia wygłoszonego do audytoriów Roty Rzymskiej. Por. AAS 58 (1966) 154.

10 Regatillo E., Las causas matrimoniales - Comentario, W: Sal Terrae 59 (1971) 630 . 
rych norm o ustanowieniu trybunałów kościelnych i o procesie sądowym, dzięki którym sam proces małżeński mógłby być skrócony".

Normy zawarte w moto proprio Causas matrimoniales mają charakter czasowy, obowiązują od dnia 1 października 1971 r. do czasu publikacji nowego kodeksu prawa kanonicznego, mają też charakter ustawodawstwa powszechnego, tak że muszą się zastosować do nich wszystkie trybunały w całym Kościele, nie wyłączając trybunałów apostolskich, wśród których będą one dotyczyć przede wszystkim Roty Rzymskiej. Normy te nie mają jednak charakteru wyłącznego, nie stanowią całości kanonicznego procesu sądowego $\mathrm{w}$ sprawach o orzeczenie nieważności małżeństwa, wnoszą jedynie pewne zmiany do przepisów proceduralnych Kodeksu Prawa Kanonicznego, względnie wprowadzają nowe dyspozycje prawne, których Kodeks nie zawierał. Normy procesowe dotychczasowego Kodeksu, o ile nie zostały w Motu proprio ${ }^{11}$ zmienione, lub przez nie odwołane, obowiązują nadal, tworząc wraz z nowymi przepisami całość ustawodawstwa kościelnego, obowiązującego przy orzekaniu nieważności małżeństwa.

\section{WEASCIWOSĆ TRYBUNAEU}

I. Sprawy małżeńskie osób ochrzczonych należa na mocy własnego prawa do sędziego kościelnego.

II. Sprawy dotyczace czysto cywilnych skutków matżeństwa należa do władzy świeckiej, chyba że prawo partykularne postanawia, iz sprawy te - gdy wyjda przypadkowo i ubocznie - moga być rozpatrzone $i$ orzeczone przez sędziego kościelnego.

III. Wszystkie sprawy małżeńskie dotyczące osób, o których mowa $w$ kan. 1557, § 1, n. 1 K.P.K., rozpatruje w sposób wyłązny kongregacja, trybunał lub specjaina komisja, którym Ojciec św. zleci w poszczególnych wypadkach prowadzenie tych spraw.

IV, § 1. W pozostałych sprawach nieważności malżeństwa jest kompetentny:

a) trybunał miejsca zawarcia małżeństwa, lub

b) trybunał miejsca, $w$ którym strona pozwana ma zamieszkanie nieprzypadkowe, co da się stwierdzić na podstawie dokumentu kościelnego, ewentualnie innym legalnym sposobem, albo

c) trybunał miejsca, w którym faktycznie trzeba będzie przyjmować większość zeznań czy dowodów, byleby wyrazili na to zgodę zarówno Ordynariusz miejsca stałego zamieszkania strony pozwanej, jak i Ordynariusz miejsca i przewodniczący trybunału, do którego wnosi się sprawę.

11 Motu proprio Causas matrimoniales oznaczam w tekście skrótem MPCM, a poszczególne jego normy cyframi rzymskimi. 
§ 2. W wypadku, o którym mowa $w$ poprzednim § 1, c., trybunat przed dopuszczeniem sprawy winien zapytać stronę pozwana, czy nie ma zastrzeżeń co do forum wybranego przez strone powodowa.

§ 3. Gdy ulegna istotnej zmianie okoliczności dotyczqce bądź miejsca, bądź osób, o których mowa $w \S 1$, wtedy, w poszczególnych wypadkach, wolno przed zamknięciem postępowania dowodowego przenieść instancję $z$ jednego trybunału do drugiego, równie właściwego, o ile wyraża na to zgode strony oraz obydwa trybunaty.

Przede wszystkim, w I normie MPCM, Ustawodawca przypomina treść kan. 1960 K.P.K. i art. 1, § 1 Instrukcji Kongregacji Sakramentów Provida, stwierdzając, że sprawy małżeńskie ochrzczonych, należą na mocy własnego prawa do sędziego kościelnego.

Do spraw małżeńskich $\mathrm{w}$ znaczeniu ścisłym należą te, które dotyczą: a) orzeczenia ważności lub nieważności małżeństwa; b) stwierdzenia dopełnienia lub niedopełnienia małżenstwa; c) trwałej lub czasowej separacji małżonków; d) rozwiązania małżeństwa ważnego lecz niedopełnionego; e) rozwiązania małżeństwa ważnego i dopełnionego, mocą przywileju Pawłowego lub przywileju wiary; f) ślubności potomstwa i innych skutków związanych istotnie $\mathrm{z}$ małżeństwem.

W zakres spraw małżeńskich w szerszym znaczeniu wchodzą te, które mają za przedmiot: a) naprawienie szkód wynikłych z rozwiązania lub niewypełnienia zaręczyn; b) wielkość posagu, prawo do alimentów, administrację dóbr, dziedziczenie itp. ${ }^{12}$.

Norma I odnosi się do spraw małżeńskich w znaczeniu ścisłym, ale jej sformułowania nie są identyczne z brzmieniem kan. 1960 i art. 1, $\S 1$ Instrukcji Provida.

Określenie kan. 1960 ,inter baptizatos" zastąpiono w normie przez „,baptizatorum”, a określenie ,iure proprio et exclusivo” przez ,iure proprio", z pominięciem „exclusivo". Ponadto w stosunku do art. 1, §1 Instrukcji Provida, w normie I opuszczono zupełnie drugą część paragrafu pierwszego, która miała brzmienie: „Idem obtinet si una tantum pars sit baptizata".

Zachodzi pytanie, co kryje się za nową redakcją tekstu.

Chcąc tłumaczyć dosłownie tekst zawarty w motu proprio należy wskazać, że jednak jurysdykcja własna, a własna i wyłączna, to przecież nie to samo. Jurysdykcja wyłączna wyklucza bowiem od możliwości

12 Cabreros de Anta IM., Reforma del proceso en las causas matrimoniales según la Carta Apostolica "Causas matrimoniales” de Pablo VI, W: Ius Canonicum, vol. XII, n. 24 (1972) 229-230. 
działania wszelką inną władzę, podczas gdy jurysdykcja własna może dopuszczać konkurencyjną.

Czyżby Kościół zmienił stanowisko w tak ważnej dla niego sprawie, jaką jest wyłączność jurysdykcji kościelnej w orzekaniu ważności lub nieważności sakramentalnego małżeństwa?

Autorzy zgodnie utrzymują, że nowa redakcja tekstu takiej zmiany stanowiska nie oznacza.

D i I o ri o uważa, że istota rzeczy nie uległa zmianie, a nowy tekst jest jedynie bardziej zwięzły i bardziej kurtuazyjny względem władzy państwowej i niekatolickich wyznań chrześcijańskich ${ }^{13}$.

Jos è A S outo wyraża podobną opinię. Pominięcie określenia „exclusivo" może być uznane tylko za ustępstwo formalne i dokonano go, jego zdaniem, celem uniknięcia sformułowań kategorycznych i wykluczających, niemile widzianych $\mathrm{w}$ dobie kryzysu autorytetu ${ }^{14}$.

C a breros de Anta skłania się do nieco innej opinii. Ponieważ dokument papieski nic nie mówi o wyłącznym prawie Kościoła do rozstrzygania spraw małżeńskich, należy - jego zdaniem - przyjąć, iż Ustawodawca chciał przez to wskazać, że Kościół może zlecić trybunałom świeckim wykonywanie prawa, które jest własnym prawem trybunałów kościelnych. Z samego milczenia nie można jednak wyciągać wniosku, że zlecenie takie jest zawarte $\mathrm{w}$ normie, a $\mathrm{z}$ samej możliwości nie wynika, by władza państwowa mogła je sobie uzurpować. Ponadto zgodnie z powszechnie przyjętą opinią, tak w nauce, jak i w praktyce kanonistów, Kościół nie powinien nigdy dzielić się tym prawem z nikim, jeśli chodzi o orzekanie ważności, czy nieważności małżeństwa sakramentalnego. Sprawy separacji małżonków natomiast, jakkolwiek należą do spraw małżeńskich. w ścisłym znaczeniu, mogą być zlecone trybunałom świeckim i Kościół czynił już niekiedy w tej sprawie ustępstwa ${ }^{15}$.

Opuszczenie w normie I drugiej części art. 1, § 1 Instrukcji Provida, nasuwa wątpliwości, czy zachował on nadal swoją moc prawną, to znaczy, czy sprawy małżeństw, w których przynajmniej jedna ze stron jest ochrzczona, podlegają nadal trybunałom kościelnym mocą własnego prawa, czy też nie.

I w tym wypadku trudno jednak mówić o zmianie. Jeśli bowiem małżeństwo między osobą ochrzczoną a nieochrzczoną jest zawierane za dyspensą kościelną od przeszkody różności wyznania, podlega w całej

13 Di Jorio O., De motu proprio Pauli pp. VI Causas matrimoniales quibusdam adnotationibus instructo, Roma 1971, s. 5.

14 Souto J., Las lineas generales de la reforma, W: Ius Canonicum, vol. XII, n. 23 (1972) 93-94. Istotnych zmian nie zauważa też Flatten H., Zur Reform des Kirchlichen Eheprozesses. Das Motu proprio Papst Paulus VI. "Causas matrimoniales" vom 28. März 1971, Köln 1971, s. 2.

15 Cabreros de Anta, dz. cyt., s. 230. 
rozciągłości prawu kanonicznemu, jeśli zaś zostało zawarte bez takiej dyspensy, jest uważane przez ustawodawstwo kościelne za nieistniejące od samego początku i trybunały kościelne nie roszczą sobie pretensji do rozpatrywania kwestii z nim związanych ${ }^{16}$.

Tekst normy I zawiera ponadto pewną nieścisłość, bo małżeństwa mieszane między osobami ochrzczonymi i nieochrzczonymi nie mogą być, ściśle rzecz biorąc, nazwane małżeństwami ochrzczonych ${ }^{17}$.

W związku z normą I postawiono dalsze pytanie: czy przepisy motu proprio Causas matrimoniales mają zastosowanie do spraw separa c ji małżonków

Odpowiedź pozytywną daje Leon del Amo Pachon, argumentując, że normy I-IV motu proprio można stosować do spraw separacyjnych, w oparciu o zasadę analogii prawnej. Jeśli proces o orzeczenie nieważności został przyspieszony, tym bardziej przyspieszyć należy załatwienie separacji, w obydwu wypadkach chodzi przecież o dobro duchowe wiernych, a separacja, która jest sprawą mniejszej wagi niż orzeczenie nieważności, nie powinna być traktowana bardziej rygorystycznie. Del A mo powołuje się ponadto na odpowiedź sekretarza Sygnatury Apostolskiej, który takie stanowisko uznał za właściwe ${ }^{18}$.

Przeciwko takiej interpretacji przemawia jednak szereg poważnych argumentów.

Motu proprio nigdzie o sprawach separacji nie wspomina, konsekwentnie zaś i wyraźnie mówi o orzekaniu nieważności małżeństwa. Ogólne brzmienie normy I, nie zawierającej żadnych ograniczeń - na co również powołuje się del Amo - nie może tutaj służyć za podstawę interpretacji, skoro we wstępie dokumentu wyraźnie powiedziano, że poza zawartymi w motu proprio przepisami pozostałe normy procesu obowiązują bez zmian. Sprawy separacyjne mają zaś własne normy, wystarczająco wyjaśnione przez praktykę sądową i nie ma powodu podciągać ich pod ustawodawstwo odnoszące się wprost tylko do orzekania nieważności małżeństwa. Nie należy się wreszcie w tym wypadku odwoływać do zasady analogii prawnej, bo ma ona zastosowanie przy interpretacji tylko wówczas, kiedy tekst ustawy nie jest jasny (kan. 18), w naszym zaś wypadku tekst sam nie budzi wątpliwości ${ }^{19}$.

Jakkolwiek sprawy separacji wymagają niewątpliwie szybkiego załatwiania, to nie wydaje się możliwe, by bez autorytatywnego orzeczenia

16 Souto J., dz. cyt., s. $94-95$.

17 Di Jorio O., dz. cyt., S. 5 .

18 Del Amo Pachon L., Neuva tramitacion de las causas matrimoniales, Salamanca 971, s. 90. List Sekretarza Sygnatury Apost. nosi datę 26 sierpnia 1971 r. i prot. $\mathrm{nr} 1987 / 71$.

19 De Diego - Lora C., Notas críticas a un comentario al $M . P$. „Causas matrimoniales", W: Ius Canonicum, vol. XII, n. 24 (1972) 265-267. 
kompetentnej władzy kościelnej, w oparciu tylko o tekst motu proprio, można było jego przepisy do tych spraw zastosowac. Odpowiedź sekretarza Sygnatury nie wystarcza, chociaż Sygnatura Apostolska mogłaby, na podstawie n. 105 konstytucji apostolskiej Regimini Ecclesiae Universae, poszerzyć właściwość trybunałów do sprawy separacji $\mathbf{2 0}^{\mathbf{0}}$.

W stosunku do ustawodawstwa kodeksowego także i norma II wprowadza zmiany.

Kodeks Prawa Kanonicznego w kan. 1961 a Instrukcja Provida w art. 1, § 2 stanowiły zasadę ogólną, że sędzia kościelny mocą własnego prawa mógł orzekać o czysto cywilnych skutkach mal$\dot{\mathrm{z}} \mathrm{e}$ n $\mathrm{s} \mathrm{wa}$, jeśli tego typu sprawy wyłoniły się w procesie przypadkowo i ubocznie.

Motu proprio Causas matrimoniales odwraca jak gdyby tę zasadę stanowiąc, że sprawy czysto cywilnych skutków małżeństwa nie należą do kompetencji sędziego kościelnego nawet wówczas, kiedy pojawią się przypadkowo i ubocznie. W takiej sytuacji może on o nich orzekać jedynie wówczas, gdy prawo partykularne przyznaje mu taką kompetencję, np. w konkordacie. Jest to więc częściowe uchylenie kan. 1961 i wyraźna rezygnacja Kościoła $z$ osądzania tych spraw ${ }^{21}$.

Dobrze się stało, że zdecydowano się na taką zmianę. Z jednej bowiem strony trudno się doszukać $w$ kwestiach związanych $\mathrm{z}$ czysto cywilnymi skutkami małżeństwa aspektu pastoralnego, który uzasadniałby interwencję Kościoła, z drugiej zaś, trybunał kościelny, ewentualnie rozstrzygający te kwestie, nie zawsze dysponował środkami do ich właściwego rozeznania, nie mógł też zapewnić egzekucji podjętemu przez siebie orzeczeniu ${ }^{22}$.

Norma III utrzymuje w mocy przepis kan. 1557, § 1, n. 1, stanowiący, że ,samemu tylko Biskupowi Rzymskiemu przysługuje prawo sądzenia tych, którzy sprawują w państwie najwyższą władzę, ich synów i córki oraz tych, którzy mają prawo bezpośredniego następstwa we władzy". W drugiej części norma ta jest skróconym powtórzeniem kan. 1962 i nie zawiera żadnych istotnych zmian. Sprawy małżeńskie osób wyjętych przepisem kan. 1557, § 1, spod jurysdykcji zwykłych trybunałów kościelnych, papież nadal będzie zlecał za każdym razem osobno, jakiejś kongregacji rzymskiej, trybunałowi lub specjalnej komisji.

Warto przypomnieć, że bez takiego zlecenia żaden trybunał nie może

20 Cabreros de Anta M., dz. cyt., s. 228-229.

21 Souto J., dz. cyt., s. 95; Di Jorio O., dz. cyt.. s. 5; Cabreros de Anta M., dz. cyt., s. 231; Flatten H., dz. cyt., s. 2; Regatillo E., dz. cyt., s. 633 oraz Del Amo Pachon L., dz. cyt., s. 90 nie dostrzegają tej zmiany twierdząc, że n. II MPCM zgadza się z kan. 1961.

22 Cabreros de Anta M., dz. cyt., s. 231. 
tych spraw prowadzić ważnie, wchodzi bowiem w grę bezwględny brak właściwości (kan. 1558, 1892, n. 1).

Sprawy małżeńskie ludzi tak wysoko postawionych w państwie budzą zainteresowanie opinii publicznej i powodują podejrzenia. Z tego względu mogą też być uciążliwe dla trybunałów lokalnych. Czy jednak utrzymanie w mocy takich przepisów rzeczywiście służy dzisiaj dobru Kościoła? Chyba nie ${ }^{23}$.

Jeśli zaś uznano, że przepisy kan. 1557, § 1, n. 1 są słuszne, należało przynajmniej skorzystać z okazji i usunąć niedoskonałości kanonu 1962. Trybunały winny być w procesie najwyższą gwarancją przy wymiarze sprawiedliwości. Jeśli się zatem jakąś sprawę odda do rozstrzygnięcia organom niewyspecjalizowanym, może się zdarzyć, że przywilej zawarty w kan. 1557, § 1, n. 1, okaże się dla uprzywilejowanego rozwiązaniem gorszym ${ }^{24}$.

Norma IV określa właściwość kościelnych trybunałów zwyczajnych, zarówno apostolskich, jak i wszystkich niższego stopnia i zawiera nowości bardzo ważne $\mathrm{z}$ praktycznego punktu widzenia.

Właściwość trybunałów kościelnych w sprawach małżeńskich była dotąd regulowana przepisami kan. 1964 Kodeksu, uzupełnionymi art. 4-12 Instrukcji Kongregacji Sakramentów Provida z 1936 r., oraz odpowiedzią Komisji Interpretacyjnej Kodeksu Prawa Kanonicznego z dnia 14 lipca 1922 r. Właściwość ta była oparta na następujących tytułach: umowy oraz zamieszkania stałego lub tymczasowego (kan. 1964).

Norma IV, § 1 motu proprio Causas matrimoniales zatrzymuje z nich jedynie tytuł umowy jako nadal aktualny. Szkoda tylko, że tytułowi temu, tak logicznie związanemu z małżeństwem nie przyznano pierwszeństwa, celem uniknięcia nadużyć, jakich źródłem może być możliwość korzystania $\mathrm{z}$ innych trybunałów konkurencyjnych ${ }^{25}$.

Tytuły właściwości, jakimi było stałe lub tymczasowe zamieszkanie, zustały zastąpione przez nowy tytuł, określony jako $\mathrm{zamieszkanie}$ nieprzypadkowe (commoratio non precaria).

Zwiastunem tej nowości były już Normy postępowania w sprawach małżeńskich, wydane przez Stolicę Apostolską dla diecezji Stanów Zjednoczonych Ameryki Północnej, które posługiwały się terminem angielskim the residency, a określone $\mathrm{w}$ ten sposób zamieszkanie uznawały za tytuł właściwości trybunału w sprawach małżeńskich ${ }^{26}$.

23 De Jorio O., dz. cyt., s. 6.

24 Souto J., dz. cyt., s. $95-96$.

25 Lefebvre C., De motu proprio „Causas matrimoniales". Animadversiones quaedam, W: Periodica de re morali canonica liturgica 2-3 (1972) 403 wraz z przypisem n. 49, gdzie powołuje się na fakty takich nadużyć, stwierdzone przez oficjała paryskiego.

26 Norma n. 7. Por. Mc Manus F., dz. cyt., s. 364. 
Co należy rozumieć przez zamieszkanie nieprzypadkowe?

Jest to przede wszystkim określenie negatywne, eliminujące pobyt przypadkowy, jak zatrzymanie się turysty $\mathrm{w}$ hotelu celem zwiedzenia miasta czy załatwienia sprawy. Jest to także określenie słabsze od zamieszkania stałego (domicilium).

Kodeks Prawa Kanonicznego zna określenie commoratio (kan. 92) i rozumie je w sensie elementu, który, jeśli posiada odpowiednie kwalifikacje, składa się na tymczasowe lub stałe zamieszkanie.

Wydaje się, że przez zamieszkanie nieprzypadkowe, można rozumieć przebywanie w sensie fizycznym, cechujące się pewną stałością, większą niż aktualny pobyt jakikolwiek, a więc przypadkowy, mniejszą zaś od pobytu ponad pół roku. Pewien element czasu, bliżej nie określony zdaje się wchodzić tutaj w rachubę ${ }^{27}$.

Element formalny, wymagany przez Kodeks Prawa Kanonicznego do nabycia zamieszkania, czyli chęć (animus) pozostania w jakimś miejscu przez pewien okres czasu, względnie brak tej chęci, nie jest już obecnie brany pod uwagę ${ }^{28}$.

Brak przypadkowości zamieszkania należy rozumieć jako moralną niemożliwość nagłej jego zmiany ${ }^{29}$.

Wydaje się, że nie należy w języku polskim tłumaczyć commoratio non precaria przy pomocy takich terminów jak pobyt, czy rezydencja. Termin pobyt zawiera pewien element przypadkowości, rezydencja jest terminem wieloznacznym. Określenie zamieszkanie nieprzypadkowe, wydaje mi się, trafnie oddaje i pewną trwałość potrzebną do commoratio i negatywny charakter określenia łacińskiego, a ponadto nie wprowadza w błąd, bo łatwo je odróżnić tak od zamieszkania tymczasowego, jak i od zamieszkania stałego.

Tak czy inaczej commoratio non precaria nie jest terminem jasnym, co - jak się tego można było spodziewać - wywołało polemiki i spowodowało powstanie różnych opinii na ten temat.

Najczęściej zamieszkanie nieprzypadkowe utożsamia się z zamieszkaniem czy pobytem stałym (commoratio habitualis) ${ }^{30}$, tym bardziej, że Ustawodawca posługuje się tym terminem w normie IV, § 1, c. Wydaje się jednak, że pobyt stały to coś więcej niż zamieszkanie nieprzypadkowe, a ponadto uważa się, że pobyt stały oznacza główne miejsce

27 Bernardini E., Il motu proprio „Causas matrimoniales”, Roma, 1972, s. 33.

28 Souto J., dz. cyt., s. 96-98; Gordon I., De m. p. "Causas matrimoniales", W: Adnotationes professorum, Romae 1972, s. 172.

${ }_{29}$ Tak w oparciu o prawo rzymskie Lefebvre C., De motu proprio, s. 404, gdzie pisze: ,precarietas ... in iure romano audit facultatem absolutam revocandi et proinde defectus precarietatis intelligendus estt de morali impossibilitate mutandi repente quamdam commorationem, quidquid sit ratio istius impossibilitatis".

30 Di Jorio O., dz. cyt., s. 7; Del Amo Pachon L., dz. cyt., s. 94; Flatten H., dz. cyt.. s. 7. Bliski tej opinii jest również Gordon I., De m. p., s. 173. 
zamieszkania, może więc być tylko numerycznie jeden, podczas gdy zamieszkań nieprzypadkowych można posiadać równocześnie kilka ${ }^{31}$.

Można również spotkać opinię, że o tyle zamieszkanie nieprzypadkowe ułatwi prowadzenie procesów małżeńskich, o ile można je będzie sprowadzić do kodeksowego zamieszkania tymczasowego. W przeciwnym wypadku trzeba się liczyć z różnymi wątpliwościami i zarzutami braku kompetencji, co $z$ kolei tylko utrudni postępowanie ${ }^{32}$.

W wypadku zgłoszenia zarzutu braku kompetencji rozstrzyga go ten sam trybunał, do którego wniesiono sprawę. Mamy tu do czynienia z właściwością względną i dlatego ma zastosowanie kan. 1628, § 1 i ewent kan. $1610, \S 2$ i 3.

Norma IV, § 1, b) motu proprio Causas matrimoniales stanowi, że właściwość trybunału w sprawach małżeńskich wynika $\mathrm{z}$ tytułu zamieszkania nieprzypadkowego strony pozwanej. Jest to wyraźne potwierdzenie znanej zasady procesowej, zawartej w kan. 1559, § 3 ,,actor sequitur forum rei". Zasadę tę naruszyły ostatnio wspomniane już Normy amerykańskie w n. 7. Dobrze się stało, że dawna zasada, stojąca na straży porządku i domniemanej niewinności pozwanego została potwierdzona. Skoro bowiem pozwany uważany jest za niewinnego, trudno obarczać go ewentualnymi ciężarami procesu, które mogłyby się okazać nieuzasadnione ${ }^{33}$.

Warto również odnotować, że Kodeks i Instrukcja Provida brały pod uwagę, przy określeniu właściwości trybunału, tylko zamieszkanie katolików. Motu proprio Causas matrimoniales w normie IV, § 1, b) zupełnie pomija rozróżnienie na katolików i niekatolików, co jest niewątpliwie przejawem ekumenizmu. Każda ze stron procesowych, niezależnie od wyznania, jest traktowana jednakowo, tzn. zamieszkanie nieprzypadkowe stanowi dla niej tytuł właściwości trybunału w sprawach małżeńskich ${ }^{34}$.

Jakie są sposoby stwierdzenia tego tytułu?

Odpowiedź na to pytanie znajdujemy również w normie IV, § 1, b) motu proprio, która mówi, że zamieszkanie to winno być stwierdzone jakimś dokumentem kościelnym, bądź innym legalnym sposobem.

Wiemy $\mathrm{z}$ całą pewnością, że nie chodzi w tym wypadku tylko o dokument publiczny, gdyż proponowane przez konsultorów określenie sposobu dowodzenia zamieszkania nieprzypadkowego, zawarte $\mathrm{w}$ słowach

31 Lefebvre C., De motu proprio, s. 405.

32 Cabreros de Anta M., dz. cyt., s. 234-235. Podobnie Souto J., dz. cyt., s. 98 i Regatillo E., dz. cyt., s. 635.

33 Zob. Pieronek T., Normy ogólne kanonicznego procesu sqadowego, Warszawa 1970 , s. 48 .

34 Lefebvre C., De motu proprio, s. 403 i 407; Lefebvre C., Il motu proprio Causas matrimoniales", Torino-Milano 1972, s. 31; Flatten H., dz. cyt., s. 4; De Diego - Lora C., La reforma del proceso matrimonial canónico, W: Ius Canonicum, vol. XII, n. 23 (1972) 109. 
ex aliquo publico regestu ${ }^{35}$, zastąpiono $\mathrm{w}$ motu proprio sformułowaniem ex aliquo ecclesiastico documento.

Dokumentem kościelnym, stwierdzającym zamieszkanie nieprzypadkowe, będzie zazwyczaj wyciąg $z$ kartoteki duszpasterskiej lub innego spisu parafialnego, co w praktyce sprowadzi się do zaświadczenia wydanego przez urząd parafialny, dziekański czy kurię diecezjalną. Są jednak dopuszczalne i inne dokumenty kościelne uznane przez prawo ${ }^{36}$. Także i inne prawnie dopuszczalne sposoby dowodzenia, np. przy pomocy świadków są $\mathrm{w}$ tym wypadku dopuszczalne, nie jest jednak do tego potrzebny wstępny proces, jaki swego czasu przepisała Kongregacja Sakramentów celem ustalenia właściwości trybunału z tytułu zamieszkania tymczasowego ${ }^{37}$.

Przy ustalaniu zamieszkania nieprzypadkowego trzeba zwrócić uwagę nie tylko na dowody, które o nim świadczą, ale także $i$ to przede wszystkim, na przyczynę tego zamieszkania. Ponadto dowód takiego zamieszkania winien być dołączony przez powoda do skargi powodowej, by trybunał, na tej podstawie, bez zwłoki mógł uznać swą właściwość ${ }^{38}$.

Obok dokumentów kościelnych, ustaleniu zamieszkania nieprzypadkowego mogą służyć także i dokumenty cywilne, przede wszystkim takie, które mocą przepisów państwowych mają na celu stwierdzenie zamieszkania ${ }^{39}$, mogą to być jednak również i środki dowodowe mniejszej wagi, jak informacje policyjne czy prasowe ${ }^{40}$.

W warunkach polskich wystarczającym dowodem zamieszkania nieprzypadkowego będzie adnotacja w dowodzie osobistym o zameldowaniu czasowym.

Motu proprio Causas matrimoniales postanawia również $\mathrm{w} n$. IV $\S 1$, c), że właściwym do przyjęcia sprawy małżénskiej jest ten trybunał, na którego terenie faktycznie trzeba będzie zebrać większość zeznań czy dowodów.

Przyczyny wprowadzenia nowego ${ }^{41}$ tytułu właściwości są proste. W wielu sprawach małżeńskich, orzekanych $\mathrm{w}$ oparciu o kodeksowe

35 Communicationes 2 (1970) 188.

36 Lefebvre C., De motu proprio, s. 406.

37 Chodzi o instrukcję Kongregacji Sakramentów z dn. 23 grudnia 1929 r. zob. AAS 22 (1930) 490. Cabreros de Anta M., dz. cyt., s. 235 uważa proces wstępny za niepotrzebny przy ustalaniu zamieszkania nieprzypadkowego. Przydatność instrukcji podkreśla natomiast Di Jorio O., dz. cyt., s. 7.

${ }_{38}$ Lefebvre C., De motu proprio. s. 401 pisze: „probatio exinde facienda est praefatae stabilitatis, praesertim indicatione rationis istius commorationis".

39 Regatillo E., dz. cyt., s. 634.

40 De Diego - Lora C., La reforma, s. 111-112. Wydaje się, że informacja prasowa jest za słabym dowodem zamieszkania nieprzypadkowego. Łatwo może być oparta na pogłosce lub celowo podana przez zainteresowanego.

${ }_{41}$ Nie jest to zupełna nowość $w$ procesie małżeńskim, czy tym bardziej w calym procesie kanonicznym, jak twierdzi Cabreros de Anta M., dz. cyt., s. 236. 
tytuły właściwości, zachodziła potrzeba zebrania pewnej ilości zeznań czy dowodów, poza terytorium podległym trybunałowi rozstrzygającemu sprawę. Jedyną drogą zaradzającą tej potrzebie było zebranie tych dowodów przez rekwizycję, czyli zwrócenie się o pomoc w procesie do innego trybunału. Postępowanie takie nie zawsze zdawało egzamin, bo trybunał wypełniający rekwizycję nie posiadał dokładnej znajomości sprawy i nawet jeśli zadanie swoje wykonywał sumiennie, mógł nie zwrócić uwagi na kwestie pozornie drobne, a jednak dla sprawy ważne. Nie zawsze przecież obrońca węzła małżeńskiego czy rzecznik sprawiedliwości mogą zawrzeć w swoich pytaniach wszystko, tym bardziej że czasem w toku zeznań mogą się ujawnić ważne problemy. Stąd, w takich wypadkach, konieczność ponawiania prośby o przesłuchanie, strata czasu, nowe wydatki. Jeszcze bardziej komplikuje się sprawa tam, gdzie trybunał zmuszony jest zwracać się o pomoc do sądów zagranicznych, posługujących się własnym narodowym językiem ${ }^{42}$.

Wychodząc naprzeciw tym wszystkim trudnościom Ustawodawca tworzy nowy tytuł właściwości trybunałów w sprawach małżeńskich, który można by nazwać tytułem większości dowodów (forum plerarumque probationum) ${ }^{43}$.

Słusznie chyba zwrócono uwagę, że tytuł ten można bez obawy nazwać funkcjonalnym kryterium określenia właściwości, wywodzącym się $\mathrm{z}$ dwóch wielkich zasad, którymi rządzić się winien cały proces, a mianowicie zasady bezpośredñiości i ekonomii procesu ${ }^{44}$, słusznie też podkreślono, że będzie on służył pewniejszemu i szybszemu biegowi spraw małżeńskich ${ }^{45}$.

Nie należy jednak stąd wnosić, że nowy tytuł usunie wszelkie trudności związane $z$ potrzebą korzystania $z$ usług innych trybunałów. Nawet zważywszy, że w pewnej fazie procesu, właśnie na skutek potrzeby zebrania dowodów gdzie indziej, można przenieść instancję do innego

Podobny przepis znaleźć można w Normach amerykańskich (n. 7), a wcześniej w dekrecie Catholica doctrina Kongregacji Sakramentów, z dn. 7 maja 1923, dotyczącym małżeństwa niedopełnionego, który w n. 8, § 2 postanawia: „Licet tamen oratori recurrere ad Ordinarium suae actualis commorationis, qui preces acceptare valet et commendare apud H.S.C., praesertim cum plerique testes audiendi in sua diocesi degant'. Por. Di Jorio O., dz. cyt., s. 7.

$42 \mathrm{Na}$ przyczyny ustanowienia nowego tytułu właściwości wskazuje zwłaszcza De Diego - Lora C., La reforma, s. 112-113 i Lefebvre C., De motu proprio, s. 407.

${ }_{43}$ Tej skróconej nazwy używa Di Jorio O., dz. cyt., s. 7. Lefebvre C., De motu proprio, s. 407-408 posługuje się jeszcze krótszym określeniem ,forum probationum". Zob. także Gordon I., De m. p., s. 174; Flatten H., dz. cyt., s. 3; Bersini F., Le nuove norme per i processi matrimoniali, W: Palestra del Clero $2-3$ (1972) 14. 44 „A este criterio sí que le podemos llamar, sin temor, criterio funcional de atribución de competencia, pues queda justificado en esos dos grandes principios que deben regir todo proceso, cuales son, el de inmediación y el de economía" - De Diego - Lora C., La reforma, s. 113.

45 Communicationes 2 (1970) 188, n. 25. 
trybunału - o czym będzie mowa za chwilę - wzajemna pomoc trybunałów nie straci nic na swej aktualności.

Jak należy rozumieć właściwość sądową z tytułu większości dowodów?

Samo określenie „pleraeque” znajdujące się w MPCM wskazuje raczej na numeryczną większość dowodów. Wiadomo jednak, że w procesie decydującą rolę odgrywa nie tyle ilość dowodów, ile ich wartość, może się też zdarzyć, że ważne dowody będą nieliczne, a jednak zadecydują o wyniku procesu. Dlatego większości tej nie należy traktować numerycznie ze zbyt wielkim rygorem, tym bardziej, że we wstępnej ocenie Ordynariuszy i przewodniczących trybunałów, którzy muszą się w sprawie wypowiedzieć, ścisłe określenie takiej większości jest po prostu niemożliwe.

Trzeba więc rozważyć wszystkie okoliczności i poddać je rozumnej ocenie ${ }^{46}$.

Normy amerykańskie, w których tytuł większości dowodów był uwzględniony $\mathrm{w}$ n. 7 domagały się, aby sędzia dekretem uznał swą właściwość, określając przy tym, że jego trybunał jest bardziej zdatny niż jakikolwiek inny do rozstrzygnięcia sprawy. MPCM tego warunku większej zdatności nie stawia, kładzie raczej nacisk na obiektywny ciężar dowodów niż na subiektywną zdatność trybunału.

Jeśli chodzi o rodzaje dowodów, trzeba wziąć pod uwagę wszystkie możliwe, zarówno zeznania stron, świadków i biegłych, jak też dokumenty ${ }^{47}$. Wprawdzie, ściśle rzecz biorąc, zeznania stron nie stanowią dowodu przeciw ważności małżeństwa (art. 117 Instrukcji Provida), to jednak przy ocenie właściwości trybunału z tytułu większości dowodów, należy na nie zwrócić większą uwagę niż na zeznania świadków ${ }^{48}$.

O przyjęciu sprawy z tytułu większości dowodów może się zwrócić do trybunału strona powodowa. Winna wówczas, w skardze powodowej, wskazać nie tylko sposób dowodzenia, ale także określić wartość przytaczanych dowodów w stosunku do wnoszonej sprawy, tak, by trybunał mógł przystąpić do rozpatrzenia własnej kompetencji. Właściwość swą może trybunał $\mathrm{w}$ takim wypadku orzec dopiero wtedy, kiedy spełnią się w a r unki przepisane w n. IV, § 1, c) MPCM, a mianowicie, kiedy wyrazi na to swą zgodę:

a) Ordynariusz miejsca stałego zamieszkania strony pozwanej;

b) Ordynariusz miejsca trybunału, do którego wnosi się sprawę;

c) Przewodniczący trybunału, do którego wnosi się sprawę.

46 Lefebvre C., De motu proprio, s. 408. Jego zdaniem ocena ta nie może być inna jak tylko „rationabilis”.

47 Gordon I., De m.p., s. 174.

48 I.efebvre C., De motu proprio, s. 408. 
Powiedziałem, że o przyjęcie sprawy z tytułu większości dowodów zwraca się do trybunału strona powodowa w skardze powodowej, w której równocześnie prosi o potrzebną zgodę zarówno Ordynariusza, jak i przewodniczącego trybunału, do którego się zwraca. Prośba o zgodę Ordynariusza miejsca stałego zamieszkania pozwanego winna być załączona do skargi ${ }^{49}$.

Nie wydaje mi się potrzebna w tym wypadku osobna prośba o charakterze wstępnym ${ }^{\mathbf{5 0}}$, gdyż określenie kompetencji trybunału winno nastąpić w związku z rozpatrywaniem skargi powodowej, zgodnie z przepisem kan. 1709, § 1 i art. 61 Instrukcji Provida. To prawda, że przepis ten nie wzbrania przeprowadzenia wstępnych badań dotyczących właściwości, opartych o osobną, wcześniejszą prośbę, ale celowość takiego działania jest wątpliwa i niezgodna z celem MPCM, którym jest przyspieszenie spraw małżeńskich.

Zgoda dwóch Ordynariuszy i przewodniczącego trybunału wymagana jest do ważności procesu ${ }^{\mathbf{5 1}}$.

Dlaczego forum większości dowodów zostało ograniczone potrzebą tylu zezwoleń?

Zgoda Ordynariusza miejsca stałego zamieszkania strony pozwanej jest wymagana $\mathrm{z}$ tego względu, że to właśnie jego trybunał powinien rozstrzygać sprawę z tytułu zamieszkania. Ustawodawca mówi tu o stałym zamieszkaniu (commoratio habitualis). Czyżby zapomniał, że dopiero co w tej samej normie IV, § 1, b) przyznał trybunałom właściwość z racji zamieszkania nieprzypadkowego? Albo więc zamieszkanie nieprzypadkowe i stałe pokrywają się ze sobą albo użycie terminu zamieszkanie stałe jest tu celowe, przez co Ustawodawca żąda zgody Ordynariusza stałego miejsca zamieszkania strony pozwanej, biorąc pod uwagę możliwość posiadania przez stronę kilku zamieszkań nieprzypadkowych 52 .

Niewątpliwie przy tej okazji można się będzie dowiedzieć, czy twierdzenie strony powodowej dotyczące większości dowodów jest prawdziwe ${ }^{53}$ i będzie można łatwiej wykryć ewentualną zmowę stron ${ }^{54}$.

Nie wszyscy zgadzają się z taką oceną tej zgody. Niektórzy autorzy uważają np., że wymaganie takiej zgody jest z punktu widzenia proce-

49 Lefebvre C., De motu proprio, s. 408.

50 Za potrzebą takiej prośby opowiadają się: Del Amo Pachon L., dz. cyt., s. 96, a za nim Gordon I., De m.p., s. 176.

51 ,...Requiritur - pisze Di Jorio O., dz. cyt., s. 8 - consensus duorum Ordinariorum et Praesidis Tribunalis aditi. Consequitur (cfr can. 105, $1^{\circ}$ coll. can. 11 et 39) quod sine hoc triplici consensu, forum invalide aditur". Flatten H., dz. cyt., s. 4 słusznie motywuje to stanowisko klauzulą dummodo.

52 Gordon I., De m.p., s. 176.

53 Del Amo Pachon L., dz. cyt., s. 96.

54 Lefebvre C., De motu proprio, s. 409. 
sowego słabo uzasadnione, a z punktu widzenia porządku prawnego niewskazane ${ }^{55}$.

Inni natomiast widzą raczej potrzebę zgody Ordynariusza miejsca zawarcia małżeństwa i miejsca zamieszkania nieprzypadkowego strony pozwanej ${ }^{56}$.

Potrzeba zgody Ordynariusza miejsca trybunału, do którego wnosi się sprawę, uzasadniania jest specjalną odpowiedzialnością, jaką Ustawodawca na niego nakłada, odpowiedzialnością za prawdziwość twierdzeń powoda, że na tym właśnie terenie, w jego sprawie, istnieje większość dowodów. Odpowiedzialność ta różni się od tej, jaka ciąży na przewodniczącym trybunału, do którego się zwrócono i jaką obarczony jest sędzia ${ }^{57}$.

Możliwe, że to jest jakiś argument, ale przyznam się, że nie przemawia mi do przekonania. Ocena prawdziwości twierdzeń powoda dokonana przez trybunał wydaje mi się $\mathrm{w}$ tym wypadku bardziej fachowa i wystarczająca. Za potrzebą zgody Ordynariusza raczej przemawia to, że skoro żąda się zgody Ordynariusza miejsca stałego zamieszkania strony pozwanej, to wypada też, by ze strony trybunału ad quod, zgodę wyraził Ordynariusz 58 .

Jeśli strona powodowa zwróciła się do trybunału regionalnego lub międzydiecezjalnego, przez Ordynariusza należy tu rozumieć biskupa, który zgodnie $\mathrm{z}$ art. 4 Norm dla trybunatów międzydiecezjalnych lub regionalnych czy międzyregionalnych $\mathrm{z}$ dnia 28 grudnia 1970 r., jest moderatorem takiego trybunału ${ }^{59}$.

Zgoda przewodnicząego trybunału, do którego whosi się sprawę jest zrozumiała sama przez się, o ile w ogóle uwarunkowanie wlaściwości trybunału wyrażeniem zgody aż przez trzy osoby ma sens. W każdym razie trudno się w takim stanowisku doszukać usprawnienia wymiaru sprawiedliwości 60 .

Wbrew opinii niektórych kanonistów ${ }^{61}$ wydaje się, że przez przewodniczącego trybunału, do którego wnosi się sprawę, trzeba tu rozumieć przewodniczącego turnusu sędziowskiego a nie oficjała. Turnus bowiem będzie rozpatrywał skargę powodową i on zwykle wypowiada się w sprawach właściwości.

55 De Diego - Lora C., La reforma, s. 114-115. Podobnie Souto J., dz. cyt., s. 98, który przytacza dość ważki argument, że wybór forum z racji zamieszkania nieprzypadkowego jest bardziej arbitralny niż wybór forum większości dowodów, a nie wymaga się przy jego użyciu niczyjej zgody.

56 Cabreros de Anta M., dz. cyt., s. 236.

57 Del Amo Pachon L., dz. cyt., s. 96.

58 Gordon I., De m.p., s. 177.

59 AAS 63 (1971) 488.

60 De Diego - Lora C., La reforma, s. 116-117.

${ }_{61}$ Gordon I., De m.p., s. 77; Di Jorio O., dz. cyt., s. 8; Flatten H., dz. cyt., s. 4; Bersini F., dz. cyt., s. 15-16. 
Jest jeszcze jeden rodzaj warunku ${ }^{62}$, względnie raczej obowiązek, który ma wypełnić trybunał przyjmujący sprawę. Winien on mianowicie, przed dopuszczeniem sprawy, zapytać stronę pozwaną, czy nie ma zastrzeżé przeciwko forum wybranemu przez stronę powodową (n. IV, § 2).

W tym wypadku pozwany może zgłosić albo zarzut braku kompetencji, ze względu na brak warunków obiektywnych do podjęcia sprawy przez trybunał, a więc jeśli strona powodowa nie wskazała większości dowodów potrzebnej do uzyskania forum (por. kan. 1610-1611; 1617; 1628, § 2), albo też zarzut stronniczości wobec trybunału (por. kan. $1614-1617 ; 1603, \S 1$, n. $2 ; 1855, \S 3)$. Zarzuty te może też wysunąć obrońca węzła małżeńskiego i rzecznik sprawiedliwości, o ile bierze udział w procesie ${ }^{63}$.

Obowiązek powiadomienia strony pozwanej jest tutaj oparty na zasadzie równości praw w procesie między procesującymi się stronami. Jeśli więc stronie powodowej przysługuje prawo skargi do określonego trybunału, stronie pozwanej musi przysługiwać jakaś forma obrony. Pytanie do strony pozwanej winno być skierowane przez przewodniczącego turnusu sędziowskiego ${ }^{64}$.

Tekst MPCM domaga się, by stronę pozwaną pytać w tej sprawie przed dopuszczeniem sprawy, a więc przed oficjalnym wezwaniem stron do sądu (por. kan. 1725, n. 2). Jeśli strona pozwana milczy, nie odpowiada, po upływie terminu można uznać, że się zgadza ${ }^{65}$.

Jak należy osądzić sytuację, w której trybunał nie zapytał strony pozwanej? Zdania są podzielone. Jedni uważają, że nie powoduje to nieważności procesu, tekst bowiem MPCM nigdzie o tym nie mówi ${ }^{66}$, inni natomiast uważają, że proces i wyrok mogą być z tego powodu nieważne, bo stronie pozwanej nie udzielono prawa obrony ${ }^{67}$. Wydaje się, że ta druga opinia jest słuszna. Jeśli bowiem warunki polegające na zgodzie Ordynariusza i przewodniczącego trybunału ad quod MPCM stawia jako istotne, a wynika to jasno z klauzuli dummodo w normie IV, § 1, c), to tym bardziej do ważności działania trybunał powinien spełnić obowiązek, od którego zależy możliwość obrony strony pozwanej.

Skargę powodową przyjmuje lub odrzuca kolegium sędziowskie. W wypadku, gdy strona pozwana oponuje zarzutem braku właściwości

62 Del Amo Pachon L., dz. cyt., s. 97; Gordon I., De m.p., s. 177. Obydwaj uważają to raczej za warunek.

63 Di Jorio O., dz. cyt., s. 8; Lefebvre C., De motu proprio, s. 409.

64 Gordon I., De m.p., s. 177.

65 Del Amo Pachon L., dz. cyt., s. 97; Lefebvre C., De motu proprio, s. 410.

66 Lefebvre C., De motu proprio, s. 410.

67 Lefebvre C., Il motu proprio, s. 31; Del Amo Pachon L., dz. cyt., s. 97-98 
lub zarzutem stronniczości, sprawę należy rozstrzygnąć zgodnie z przepisami obowiązującymi przy sprawach wpadkowych ${ }^{68}$.

Decyzja trybunału o właściwości $z$ tytułu większości dowodów powinna być podejmowana bardzo ostrożnie. Niebezpieczeństwo jest oczywiście największe w wypadku zmowy stron, jeśli bowiem strona pozwana jest przeciwna powodowej, stosunkowo łatwo zdemaskuje wobec trybunału jej nieuczciwość ${ }^{69}$. Dlatego też postulat wyrażony przez D el A m o, by do przyjęcia sprawy $\mathrm{w}$ oparciu o ten tytuł właściwości wymagać uprzedniej zgody obydwu stron ${ }^{70}$, wydaje się tylko wzmagać niebezpieczeństwo zmowy i wydatnie utrudniać korzystanie $\mathrm{z}$ tego forum, gdyż uzyskanie zgody skłóconych ze sobą stron jest zwykle bardzo trudne ${ }^{71}$.

Dalszą nowością normy IV jest $\S 3$, pozwalający przenieść instancje z jednego kompetentnego trybunału do d rugi e go, przed zamknięciem postępowania dowodowego, przy zachowaniu szeregu warunków ograniczających.

By zilustrować, czym jest ta możliwość, streszczę uwagi, jakie na ten temat poczynil Cabreros de Anta.

Możliwość przeniesienia instancji jest wprowadzeniem do procesu małżeńskiego radykalnej zmiany. Jedną z ogólnych zasad procesu sądowego było nabycie i utrwalenie jurysdykcji sędziego, w sprawie, którą legalnie uczynił własną przez pozew. Zasada ta mieści się w kan. 1725, n. 2. Legalne wezwanie przed sąd stron procesowych powodowało wykluczenie właściwości innych sędziów w tej sprawie (kan. 1568) mocą zasady wyprzedzenia. Wszelka interwencja innego sędziego w tak przyporządkowaną sobie przez trybunał sprawę była nieważna $\mathrm{z}$ powodu bezwzględnego braku właściwości. Otóż obecnie, zasada utrwalenia jurysdykcji sędziego została istotnie zmieniona w sprawach małżeńskich. Nie może cieszyć ta zmiana ogólnych zasad procesu kanonicznego w postępowaniu w sprawach małżeńskich, gdyż byłoby lepiej normy ogólne zachowywać we wszystkich procesach. Jeśli zmiany wprowadzone w procesie małżeńskim są tak ważne, czy nie naleźałoby z nich uczynić normy ogólnej? Cabreros de Anta nie jest jednak największym pesymistą w stosunku do tej nowej instytucji, bo uznaje jej użyteczność w niektórych sprawach ${ }^{72}$, B e r n a rdini natomiast neguje całkowicie jej użyteczność ${ }^{73}$, a C a rmelo de Di ego-Lor a sądzi nawet, że może ona zaszkodzić szybkiemu przeprowadzaniu procesu, a w ogóle czyni go bardzo elastycznym ${ }^{74}$.

68 Lefebvre C., De motu proprio, s. 404.

69 Cabreros de Anta M., dz. cyt., s. 237.

70 Del Amo Pachon L., dz. cyt., s. 98.

71 Cabreros de Anta M., dz. cyt., s. 237.

72 Cabreros de Anta M., dz. cyt., s. 237-238.

73 Bernardini E., dz. cyt., s. 37.

74 De Diego - Lora C., La reforma, s. 118-119. 
Nie wszyscy jednak tak oceniają tę nowość, ale wprost uznają wielką użyteczność instytucji przeniesienia instancji, zwłaszcza w dzisiejszych warunkach migracji ludności ${ }^{75}$.

Przepis MPCM o przeniesieniu instancji znajduje swój odpowiednik w n. 12 Norm amerykańskich. Przepis normy MPCM jest od normy amerykańskiej o tyle odmienny, że nie zastrzega możliwości prośby o przeniesienie instancji dla strony powodowej i bliżej określa etap procesu, podczas którego przeniesienie takie może mieć miejsce. Precyzuje ponadto, jakie powody wystarczają do podjęcia decyzji przeniesienia instancji.

W Normach amerykańskich jest mowa, że o przeniesienie instancji może prosić strona powodowa. Co prawda, w procesie obydwie strony mają równe prawa, stąd też logicznie można wnosić, że i strona pozwana, w podobnych okolicznościach może prosić o to samo. Normy jednak nie wspominają o prawach pozwanego.

Przepis n. IV, § 3 MPCM zdaje się wskazywać na to, że inicjatywa przeniesienia instancji może wyjść także i od innych osób czuwających nad przebiegiem procesu, a więc z urzędu od sędziego instruktora, od obrońcy węzła lub rzecznika sprawiedliwości. Nie kto inny bowiem, a oni właśnie najszybciej zauważą i ocenią, że taka zmiana posłuży lepszemu załatwieniu sprawy ${ }^{76}$.

Norma dotycząca przeniesienia instancji może mieć również zastosowanie wówczas, gdy okaże się, że większość dowodów jest do zebrania na terenie podległym innemu trybunałowi i ich zdobycie przez trybunał prowadzący sprawę nastręcza trudności ${ }^{77}$.

Do przeniesienia instancji wymagane jest spełnienie szeregu w a r unków.

1. Pierwszym $z$ nich to istotna zmiana okoliczności mi j s c a l u b os ób. Kiedy zachodzi istotna zmiana? Wówczas, kiedy niesie z sobą ważne skutki dla wyniku sprawy ${ }^{78}$. Istotną zmianę okoliczności miejsca lub osób może spowodować przeniesienie się strony procesowej na inne miejsce, $z$ którego kontakt $z$ trybunałem prowadzącym sprawę jest trudny, zmiana zamieszkania przez znaczną ilość świadków, większa przydatność innego trybunału do instrukcji sprawy, zaniedbanie

75 Cabreros de Anta M., dz. cyt., s. 239; Lefebvre C., De motu proprio, s. 410; De Diego - Lora C., La reforma, s. 121. Według tego autora przeniesienie instancji może nastąpić tylko na wniosek stron i obrońcy węzła, nigdy zaś z inicjatywy trybunału, który, raz utrwaliwszy swą jurysdykcję, nie może się jej ex offiçio zrzekać.

76 Gordon I., De m.p., s. 186.

77 Del Amo Pachon L., dz. cyt., s. 99.

78 Gordon J., De m. pr., s. 183. 
procesu przez stronę powodową z równoczesnym przejęciem inicjatywy procesowej przez stronę pozwaną i inne podobne okoliczności ${ }^{79}$.

Norma mówi o zmianie istotnych okoliczności miejsca lub osób, nie wspomina natomiast o istotnej zmianie przedmiotu sporu $\mathrm{np}$. o zmianie tytułu nieważności małżeństwa, dlatego też, jeśli podczas procesu wyłoni się nowy tytuł nieważności małżeństwa, nie może nastąpić zmiana instancji 80 .

2. Przeniesienia instancji można dokonać tylko w poszczególnych wypadkach. Klauzula ta oznacza, że Ustawodawca chce zachować zasadę utrwalenia jurysdykcji trybunału, nabytej przez wezwanie stron. Bo skoro przeniesienie instancji może nastąpić tylko wyjątkowo, ogólna zasada uszczerbku nie ponosi.

3. Przeniesienie może nastąpić przed $\mathrm{zamknięciem} \mathrm{postę-}$ powania dowodowego, ściślej mówiąc od momentu wezwania stron przed trybunał (kan. 1725, nn. 2 i 5) aż do zamknięcia postępowania dowodowego. Racja tego przepisu wydaje się być ta, że po zebraniu dowodów w sprawie, trudno już mogą zaistnieć istotne okoliczności, które rzutowałyby na wynik sprawy. Przeniesienie instancji ma ten cel, by instrukcja sprawy mogła być szybsza i lepsza, a więc po zakończeniu instrukcji traci ono swój sens, co więcej, rzuca podejrzenie na stronę proszącą o to przeniesienie, że chce go dokonać celem wykluczenia sędziów wyznaczonych do wyrokowania lub dla opóźnienia rozstrzygnięcia sprawy ${ }^{81}$.

Gdyby jednak przeniesienie instancji nastąpiło po zamknięciu postępowania dowodowego? Czy proces i wyrok byłyby ważne? Mimo wszystko proces i wyrok będą ważne, o ile zostały zachowane inne warunki. $\mathrm{Na}$ taką interpretację wskazuje kan. 1861, § $1^{82}$.

4. Instację można przenieść $\mathrm{z}$ jednego właści w e go trybunału do innego, równie właściwego.

Przeniesienie instancji, jak $\mathrm{z}$ tego wynika, dokonuje się na jednej płaszczyźnie jurysdykcyjnej, a nie z trybunału niższego do trybunału wyższego stopnia.

Obydwa trybunały muszą być równie właściwe, chociaż właściwość każdego $\mathrm{z}$ nich może wypływać $\mathrm{z}$ innych lub $\mathrm{z}$ tych samych tytułów ${ }^{83}$. Tak np. jeśli trybunał a quo przyjął sprawę z tytułu zamieszkania nieprzypadkowego, nic nie stoi na przeszkodzie, by po przeniesieniu znalazła

79 Cabreros de Anta, M., dz. cyt., s. 238; Lefebvre C., motu proprio, s. 411; De Diego - Lora C., La reforma, s. 119-120; Di Jorio O., dz. cyt., s. 8; Del Amo Pachon L., dz. cyt., s. 99.

80 Cabreros de Anta M., dz. cyt., s. 238.

81 Del Amo Pachon L., dz. cyt., s. 100, a za nim Gordon I., De m.p., s. 183.

82 Lefebvre C., De motu proprio, s. 412.

83 Gordon I., De m.p., s. 184. 
się ona $\mathrm{w}$ trybunale właściwym $\mathrm{z}$ tytułu umowy, $\mathrm{z}$ tytułu większości dowodów, czy też z tytułu zamieszkania nieprzypadkowego ${ }^{84}$.

Ponieważ dwa trybunały nie mogą równocześnie rozpatrywać tej samej sprawy (kan. 156j), jest rzeczą jasną, że $\mathrm{z}$ chwilą przeniesienia instancji ustaje jurysdykcja trybunału a quo, a nabywa ją trybunał ad quod 85 i tylko on może wydać w tej sprawie wyrok. Powoduje to oczywiście skutki prawne dotyczące apelacji, którą należy kierować do trybunału będącego apelacyjnym nie dla trybunału a quo, ale dla tego, który przejął sprawę po przeniesieniu instancji.

5. Do przeniesienia instancji wymagana też jest $\mathrm{zg}$ oda $\mathrm{str}$ o $\mathrm{n}$, co jest uzasadnione równością stron $\mathrm{w}$ procesie. Przeniesienie instancji, postulowane przez jedną ze stron, może być szkodliwe lub uciążliwe dla drugiej.

Co jednak zrobić w takiej sytųacji, kiedy jedna strona stara się o przeniesienie i rzeczywiście przeniesienie takie jest uzasadnione, a druga strona nie wyraża zgody? Pytanie to ma duże znaczenie praktyczne. Często $\mathrm{w}$ procesach małżeńskich skłócone ze sobą strony robią wszystko, by sobie wzajemnie przeszkodzić, tym bardziej więc nie wyrażą zgody na przeniesienie, zwłaszcza jeśli będzie ono korzystne tylko dla jednej strony.

Odpowiedź nie jest zupełnie prosta.

Podczas gdy jedni sądzą, że zgoda stron jest potrzebna do ważności przeniesienia instancji ${ }^{86}$, inni uważają rzecz za niejasną i wskazują na potrzebę autentycznej interpretacji $\mathrm{w}$ tym względzie ${ }^{87}$.

Nie przecząc, że strony mogą w podobnych sytuacjach działać złośliwie, skłonny jestem raczej uznać rację tych, którzy zgody stron wymagają do ważności przeniesienia, a w konsekwencji i wyroku. Przemawia za tym cała nauka kanonistyki o attentacie. To prawda, że MPCM bardzo zmieniło oblicze procesu małżeńskiego, że naruszyło wiele w nim obowiązujących kanonów. Rzecz jednak w tym wypadku wygląda poważniej, zwłaszcza gdy strona nie wyraża zgody na przeniesienie instancji, może to uzasadnić względami własnej obrony.

MPCM zupełnie milczy o udziale obrońcy węzła małżeńskiego przy przenoszeniu instancji. I znów opinie kanonistów są podzielone, tym bardziej że Normy amerykańskie (n. 12) wyraźnie domagały się tu jego interwencji. Podtrzymujący opinię o po-

84 Del Amo Pachon L., dz. cyt., s. 101; Di Jorio O., dz. cyt., s. 8. Możliwość wyboru istnieje tylko między tymi trzema tytułami właściwości.

85 Gordon I., De m.p., s. 184.

86 De Diego - Lora C., La reforma, s. 120; Cabreros de Anta M., dz. cyt., s. 239; Del Amo Pachon L., dz. cyt., s. 105.

${ }_{87}$ Ferrata J. - Napoleoni H., Notationes quaedam super litteris apostolicis "Causas matrimoniales", Città del Vaticano 1972, s. 6-7. Skłania się do tej opinii także Gordon I., De m.p., s. 185. 
trzebie votum obrońcy węzła małżeńskiego zwracają uwagę na jego uprzywilejowane stanowisko $\mathrm{w}$ procesie małżeńskim i konieczność interwencji na każdym etapie tego procesu, zgodnie z kanonami 1586-1587 i 1967-1969, oraz art. 15 i 70—72 Instrukcji Provida ${ }^{88}$. Niektórzy jednak uważają, że votum obrońcy węzła małżeńskiego nie jest tu potrzebne, ponieważ wszystkie trybunały kościelne działają w sprawach małżeńskich przy stałym udziale obrońcy węzła ${ }^{89}$. Rozumowanie to nie jest przekonywujące i raczej przemawia za udziałem obrońcy w akcie przeniesienia instancji. Zgodnie $z$ art. 15, § 1 Instrukcji Provida „obecności obrońcy węzła małżeńskiego wymaga się zawsze w toku procesu". Normy MPCM natomiast nie odwołują dotychczasowego ustawodawstwa odnoszącego się do działania obrońcy węzła w tej fazie procesu, po prostu nic na ten temat nie mówią. $\mathrm{Z}$ milczenia zaś Ustawodawcy trudno wyciągać tak daleko idące wnioski. Jeśli bowiem nie wymaga się interwencji obrońcy węzła małżeńskiego przy przenoszeniu instancji w trybunale a quo, trudno wymagać takiej interwencji również od obrońcy węzła w trybunale ad quod, z czego wynika, że w tej ważnej fazie procesu, spowodowanej przecież istotną zmianą okoliczności osób lub miejsca, obrońca węzła w ogóle nie bierze udziału. Nie rozumiem zatem, jak można uznać tezę o stałym udziale obrońcy węzła w procesie za argument przeciw jego interwencji w wypadku przeniesienia instancji. Warto zaznaczyć, że w wypadku obrońcy węzła małżeńskiego nie chodzi o jego formalną zgodę, ale raczej o interwencję w formie votum i ewentualnie o możliwość przeciwstawienia się przeniesieniu instancji. Sprzeciw taki musi być wzięty pod uwagę przez trybunały podejmujące decyzję.

6. Zgoda samych stron procesowych nie wystarcza jednak do przeniesienia instancji. Potrzebna jest ponadto $\mathrm{zgoda}$ obydwu trybunałów.

Trybunał a quo jest $\mathrm{w}$ posiadaniu sprawy, utrwalił $\mathrm{w}$ stosunku do niej swą jurysdykcję, ma prawo ją prowadzić i zakończyć wyrokiem, trudno więc dokonywać $\mathrm{w}$ tym stanie zmiany bez zgody zainteresowanego trybunału. Tenże trybunał zna sprawę i łatwo potrafi rozeznać, czy przeniesienie instancji jest z pożytkiem dla wymiaru sprawiedliwości, czy też raczej manewrem stron, obliczonym na uzyskanie własnych celów.

Także i trybunał ad quod musi wyrazić zgodę. Przyjmuje on bowiem do rozeznania i rozstrzygnięcia sprawę już zaczętą i prowadzoną przez kogo innego. Przejęcie jej jest pewnym ryzykiem i przyjęciem na siebie odpowiedzialności za cudzą pracę, nic więc dziwnego, że nie narzuca się trybunałowi tej sprawy, lecz wymaga się jego zgody ${ }^{90}$.

${ }_{88}$ Zwłaszcza Del Amo Pachon L., dz. cyt., s. 104.

89 Lefebvre C., Il motu proprio, s. 34; Gordon I., De m.p., s. 185.

90 Del Amo Pachon L., dz. cyt., s. 105-106; Gordon I., De m.p., s. 185. 
Należy zwrócić uwagę, że na przeniesienie instancji muszą wyrazić zgodę obydwie strony procesowe i obydwa trybunały. Ma to zapobiec najpierw niebezpieczeństwu zmowy stron i wykorzystaniu tej możliwości do wprowadzenia trybunału $\mathrm{w}$ błąd, a następnie uchronić także strony procesowe przed ewentualnymi nadużyciami ze strony trybunałów. Nie mogą one zrzekać się prowadzenia raz przyjętych spraw, na rzecz innych trybunałów według tylko własnego uznania i bez udziału stron. Prowadziłoby to do zdezorganizowania całego sądownictwa kościelnego ${ }^{91}$.

Pozostaje jeszcze do omówienia kilka kwestii związanych z otwarciem przez Ustawodawcę drogi do przeniesienia instancji.

Pierwsza kwestia dotyczy odpowiedzi na pytanie, czy przeniesienie sprawy może mieć miejsce tylko podczas procesu w pierwszej, czy takż i w drugiej instancji.

Samo pytanie powstaje stąd, że MPCM omawia całą problematykę przeniesienia instancji $\mathrm{w}$ rozdziale poświęconym właściwości trybunałów pierwszej instancji. Wiadomo zaś, że istotne zmiany okoliczności miejsca lub osób mogą zaistnieć także i w drugiej instancji, zwłaszcza wówczas, gdy dochodzi w niej do uzupełnienia instrukcji procesu.

Di J o ri o ogranicza możliwość przeniesienia sprawy tylko do trybunałów pierwszej instancji, nawet w takich wypadkach, gdyby w trybunale drugiej instancji należało uzupełnić instrukcję procesu i była potrzeba dokonania jej na innym terenie. Autor nie uzasadnia bliżej swego stanowiska. Solidnego argumentu używa tylko w stosunku do Roty Rzymskiej jako ewentualnego trybunału pierwszej instancji. Ponieważ Rota prowadzi sprawy małżeńskie w pierwszej instancji wyłącznie na podstawie zlecenia papieskiego (kan. 1559, § 2), nie wchodzi w rachubę jako normalny partner do przeniesienia instancji, w stosunku do innych trybunałów tejże instancji ${ }^{92}$.

Gordon i Bersini zajmują w tej kwestii inne stanowisko. Uważają mianowicie, że nie ma powodów, by ograniczać możliwość przeniesienia instancji do trybunałów pierwszego stopnia. Argumentują po prostu tym, że sytuacja, która skłoniła Ustawodawcę do zezwolenia na przeniesienie instancji w trybunałach pierwszego stopnia, może mieć miejsce i w trybunałach wyższego stopnia, rozpatrujących sprawę w drugiej instancji. Z natury swej zatem norma MPCM nie może dotyczyć wyłącznie pierwszej instancji ${ }^{93}$.

To drugie stanowisko jest bardziej przekonujące.

91 Lefebvre C., De motu proprio, s. 412.

92 Di Jerio O., dz. cyt., s. 9.

93 Gordon I., De m.p., s. 187; Bersini F., dz. cyt., s. 21. 
Ponieważ argument z kan. 1559, § 2 nie dotyczy instancji apelacyjnej, wydaje się, że na tym szczeblu instancja mogłaby być przeniesiona także i do Roty Rzymskiej.

Druga kwestia dotyczy zgody wyrażanej na przeniesienie instancji przez obydwa trybunały. Kto właściwie ma podjąc decyzję w tej sprawie: przewodniczący kolegium sędziowskiego, kolegium jako takie, czy też oficjał?

I tutaj brak jest zgodnych odpowiedzi.

B e r sin i zostawia podjęcie decyzji oficjałowi ${ }^{94}$, inni w większości uważają, że należy ono do kolegium. Argumentacja w tym wypadku jest różna. D el A mo wychodzi z założenia, że wyrażenie zgody lub jej odmowa jest tak ważną decyzją, że musi ją podjąć kolegium. Jeśli ono właśnie przyjmuje lub odrzuca skargę powodową, wydaje się logiczne, by w sprawie nie mniej ważnej, jaką jest przeniesienie instancji, również wypowiedziało się kolegium ${ }^{95}$. G ordon natomiast dochodzi do tego samego wniosku, wskazując raczej na sposób podjęcia decyzji. Ponieważ przeniesienie instancji jest traktowane w procesie jako sprawa wpadkowa, do kolegium należy jej dopuszczenie i rozstrzygnięcie dekretem lub wyrokiem przedstanowczym (por. Instrukcja Provida, art. 189$-193)^{96}$.

Trzecia kwestia dotyczy ewentualnych wypadków, w których dla właściwego zakończenia procesu byłaby pożyteczna zmiana instancji i przeniesienie sprawy do innego trybunału niż przewidziano w MPCM, względnie zaszła $\mathrm{w}$ sprawie istotna zmiana okoliczności, nie dotycząca jednak ani miejsca, ani osób, a np. zbyt wolnego prowadzenia sprawy. Czy istnieje jakieś wyjście z tej sytuacji?

Otóż w każdym z takich wypadków można się zwrócić do Sygnatury Apostolskiej, która może na taką zmianę wyrazić zgodę ${ }^{97}$.

I jeszcze jedna sprawa o znaczeniu praktycznym. W jaki sposób należy załatwiać przeniesienie instancji?

L ef ebvre radzi, by strona procesowa, której zależy na przeniesieniu, zwróciła się najpierw do trybunału ad quod i zapewniła sobie u niego gotowość przyjęcia sprawy. Dopiero wówczas należałoby zwrócić się do trybunału a quo, który ze swej strony wyrazi zgodę na przeniesienie. Jeśli zaś o przeniesienie instancji zwraca się obrońca węzła małżeńskiego lub sam trybunał ex officio, nic nie stoi na przeszkodzie, by sam trybunał a quo zajął się załatwieniem sprawy ${ }^{98}$.

94 Btrsini F., dz. cyt., s. 20.

95 Del Amo Pachon L., dz. cyt., s. 107.

96 Gordon I., De m.p., s. 187.

97 Konstytucja Apostolska Regimini Ecclesiae Universae, n. 105 - AAS 59 (1967) 921. Por. Gordon I., De m.p., s. 188; Di Jorio O., dz. cyt., s. 9.

s8 Lefebvre C., De motu proprio, s. 412. 
Wydaje się, że całą sprawę, niezależnie od tego, kto jest jej inicjatorem, należy załatwić drogą urzędową, a więc przez trybunał a quo, który na interwencję stron, obrońcy węzła czy ex officio, powiadamiając o tym wypadku obrońcę i uzyskawszy zgodę stron, zwraca się do trybunału ad quod. Po uzyskaniu przyrzeczenia zgody trybunału ad quod, trybunał a quo wydaje umotywowany dekret, w którym wyraża zgodę na przeniesienie instancji. Dopiero wówczas instancja rzeczywiście przestaje należeć do pierwszego trybunału i może być przyjęta również umotywowanym dekretem przez trybunał ad quod.

Sprawa, przyjęta w ten sposób przez drugi trybunał, nie może wrócić do pierwszego, chyba że na nowo zaistniały wszystkie warunki potrzebne do przeniesienia instancji ${ }^{99}$. Trybunał, który przejął sprawę, winien ją zakończyć wyrokiem. Apelację od tego wyroku kieruje się do trybunału będącego, zgodnie $z$ przepisem kan. 1594, § $1-3$, apelacyjnym dla trybunału, który wydał wyrok.

\section{POWOEANIE TRYBUNAEÓW}

$V, \S 1$. Jeżeli ani $w$ trybunale diecezjalnym, ani $w$ trybunale regionalnym - gdzie taki został erygowany - nie można powołać kolegium złożonego $z$ trzech sędziów duchownych, wtedy Konferencja Biskupia otrzymuje upoważnienie do zezwalania, by zarówno $w$ pierwszej, jak $i$ drugiej instancji powoływać kolegium złożone $z$ dwóch duchownych $i$ jednego mężczyzny świeckiego.

$\S$ 2. Gdy w pierwszej instancji nie można ukonstytuować.kolegium nawet przez dołaczenie mężczyzny świeckiego, o którym mowa w § 1, wtedy na zlecenie Konferencji Biskupiej sprawy orzeczenia nieważności małżeństwa moga być powierzone $w$ poszczególnych wypadkach duchownemu, działajacemu jako trybunał jednoosobowy. Tam, gdzie to możliwe, sędzia taki winien sobie dobrać do prowadzenia sprawy ławnika $i$ audytora.

§ 3. Zgodnie z własnymi statutami Konferencja Biskupia może udzielać zezwoleń, o których była wyżej mowa, albo przez zespót członków (komisję), albo przynajmniej przez członka Konferencji, specjalnie do tego powołanych.

VI. Funkcję ławnika i audytora można powierzać mężczyznom świeckim $w$ trybunałach wszystkich stopni. Natomiast funkcje notariusza moga petnić zarówno mężczyźni, jak i kobiety.

VII. Osoby świeckie, którym powierza się tego rodzaju funkcje, winny się odznaczać wiara katolicka $i$ dobrymi obyczajami, jak równiė̇

99 Cabreros de Anta M., dz. cyt., s. 239. 
posiadać wiedzę kanoniczna. Gdy zaś idzie o powierzenie mężczyźnie świeckiemu funkcji sędziego, o czym mowa $w n$. $V, \S 1$, to na pierwszym miejscu należy postawić osoby posiadajace praktyke sadowa.

Przepisy n. V-VII MPCM, jakkolwiek zatytułowane „powołanie”, wzgl. ,ukonstytuowanie się" trybunałów, zawierają kilka bardzo ważnych szerszych problemów dla współczesnego sądownictwa kościelnego.

Ukonstytuowanie się trybunału kościelnego $\mathrm{w}$ procesie małżeńskim, według przepisów kodeksowych, w wielu krajach, zwłaszcza misyjnych, napotykało od dawna na trudności, wynikające $\mathrm{z}$ braku wystarczającej ilości księży o odpowiednich kwalifikacjach.

Chcąc zaradzić przynajmniej częściowo tym trudnościom, Ojciec św. dokonał w MPCM zasadniczego i śmiałego kroku, ot wi er a ją c mo żliwość udziału osób świeckich w pracy sądów kości elnych, zastrzeżonej dotychczas, prawie całkowicie, dla księży.

W tym samym celu reformie uległy przepisy odnoszące się do udziału w procesie małżeńskim trybunału kolegialnego. I w tym wypadku MPCM przewiduje mózliwość powołania trybunału jedno.osobowego w sprawach małżeńskich.

Wokół tych dwóch ważnych problemów obraca się całe ustawodawstwo MPCM o powoływaniu trybunałów, przy czym rozwiązania, jakie znajdujemy $\mathrm{w}$ normach tego dokumentu, wzbudziły bardzo burzliwą dyskusję, którą postaram się również krótko zreferować.

Już w normie V, § 1 na pierwszy plan wysuwa się sprawa udziału świeckich $\mathrm{w}$ procesie małżeńskim $\mathrm{w}$ roli sędziego i sprawa trybunału kolegialnego.

Najpierw warto zwrócić uwagę, że MPCM utrzymuje w mocy zasadę kan. 1576, § 1, n. 1 i art. 13 Instrukcji Provida, która głosi, że sprawy węzła małżeńskiego, po odrzuceniu jakiegokolwiek przeciwnego przywileju czy zwyczaju, zarezerwowane są trybunałowi kolegialnemu złożonemu z trzech sędziów: z przewodniczącego kolegium, którym jest oficjał lub wiceoficjał i z dwóch sędziów synodalnych (art. 14 Instrukcji Provida). Wszyscy członkowie kolegium musieli być, według norm Kodeksu, kapłanami (kan. 1573, § 4 i 1574, § 1). Wyrok wydany przez inny trybunał niż kolegialny byłby wyrokiem nieważnym (kan. 1892, n. 1).

MPCM, uznając zasadę trybunału kolegialnego w sprawach małżeńskich za nadal obowiązującą, wprowadza normę o charakterze pomocniczym ${ }^{100}$, określającą, że tylko wówczas, kiedy w sądzie diecezjalnym lub regionalnym nie można ukonstytuować trybunału kolegialnego, złożonego $\mathrm{z}$ trzech duchownych (clericorum), dopuszczalne jest, pod pewnymi wa-

100 De Diego - Lora C., La reforma, s. 123-124. 
runkami, powołanie trybunału kolegialnego, złożonego z dwóch duchownych i jednego świeckiego mężczyzny.

Pierwsza now'ość, jaka spotykamy w tym przepisie, dotyczy stwierdzenia, że trybunał kolegialny może być złożony $\mathrm{z}$ tr z e ch d u chownych, a nie jak dotychczas z trzech kapłanów. Określenie clerici, po dokonanej niedawno reformie tonsury, święceń niższych i subdiakonatu w Kościele łacińskim ${ }^{101}$, zwłaszcza zaś po wydaniu norm dotyczących diakonatu ${ }^{102}$, obejmuje kapłanów i diakonów. Udział diakonów zatem w kolegium sędziowskim w sprawach małżeńskich został przyjęty jako norma ogólna i nie wymaga żadnych dodatkowych zezwoleń ${ }^{103}$, o czym świadczy dekret Sygnatury Apostolskiej z dnia 9 września 1972 r., stwierdzający, że nic nie stoi na przeszkodzie nominacji diakona, o ile spełnia inne stawiane w sprawie wymagania, na urząd sędziego prosynodaln̨ego 104.

Niemożliwość ukonstytuowania trybunału kolegialnego złożonego z trzech duchownych jest warunkiem, bez zaistnienia którego nie można tworzyć trybunału z udziałem osób świeckich.

Niemożliwość tę należy rozumieć w sensie moralnym, nie bezwzględnym, a więc jako wielką niedogodność, trudną do przezwyciężenia, powstałą na skutek dotkliwego braku duchownych w ogóle lub też braku takich duchownych, którzy mają odpowiednie przygotowanie do pracy w trybunale ${ }^{105}$.

Jeśli jednak taka niemożliwość zachodzi, wówczas Konferencja Biskupia może zezwolić na udział jednego świeckiego mężczyzny w kolegium sędziowskim.

W związku z tą nowością rozważana jest w kanonistyce na nowo sprawa możliwości wykonywania przez świeckich jurysdykcji kościelnej i problem charakteru wyroku w sprawach małżeńskich ${ }^{106}$.

Skoro bowiem świeccy mogą wchodzić w skład kolegium sędziowskiego i w tym kolegium wykonują normalne funkcje sędziowskie, są po prostu sędziami kościelnymi, którym kanonistyka przypisuje wykonywanie sądowej jurysdykcji kościelnej zakresu zewnętrznego i władzy

101 Motu proprio pap. Pawła VI Ministeria quaedam z dnia 15 sierpnia 1972 r. - AAS 64 (1972) 529-534.

102 N. IX: „Ingressus in statum clericalem et incardinatio alicui dioecesi ipsa ordinatione Diaconali habentur" - Motu proprio pap. Pawła VI Ad pascendum populum, z dnia 15 sierpnia 1972 r. - AAS 64 (1972) 534-540.

103 Cabreros de Anta M., dz. cyt., s. 240.

104 Zob. Jurisprudentia Supremi Tribunalis Signaturae Apostolicae, W: Periodica de re morali canonica liturgica 4 (1972) 682.

105 Del Amo Pachon L., dz. cyt., s. 108; Gordon I., De m.p., s. 192.

106 Dyskusję na ten temat referuję za Gordonem I., De m.p., s. 190-192. 
administracyjnej ${ }^{107}$. Jeśli tak, nic nie stoi na przeszkodzie, by i w innych sprawach mogli otrzymać władzę jurysdykcyjną.

Takiemu tłumaczeniu zdaje się sprzeciwiać nauka Soboru Watykańskiego II, który, jakkolwiek bardzo podkreśla rolę świeckich w Kościele, to jednak ściśle łącząc funkcję rządzenia (munus regendi) ze święceniami biskupimi wprost (Lumen gentium, n. 21), pośrednio zaś i z kapłańskimi, wyklucza świeckich od funkcji rządzenia, w skład której wchodzi władza sądowa 108 .

Nie wszyscy zgadzają się z tą opinią, przytaczając argument, że wyrok w sprawach małżeńskich nie jest, ściśle rzecz biorąc, aktem jurysdykcyjnym, a tylko po prostu deklaracją, orzeczeniem stwierdzającym ważność lub nieważność małżeństwa jako umowy.

Argument ten jest jednak raczej grą słów. Sędzia kościelny, wydając wyrok w sprawach małżeńskich, rzeczywiście wykonuje władzę. Jego orzeczenie ma moc wiążącą dla stron tak samo, jak wyrok w każdej innej sprawie i pozwala lub zabrania zawrzeć nowe małżeństwo.

Jak zatem rozwiązać dylemat powstały na tle nauki Soboru Watykańskiego II, przez dopuszczenie świeckich do roli sędziów w sprawach małżeńskich?

Prawdą jest, że Sobór ściśle łączy funkcję sądzenia ze święceniami i dlatego nie dopuszcza, by nie posiadający święceń przejmowali w całości władzę, która wiąże się ściśle $z$ kapłaństwem. Sobór nie sprzeciwia się natomiast, by władza ta była częściowo delegowana osobom świeckim np. w kwestiach sądowych. Ponadto trzeba wziąć pod uwagę, że przedstawiony wyżej problem był dobrze znany Ustawodawcy ${ }^{109}$, skoro więc rozstrzygnął go na korzyść udzialu świeckich w trybunałach kościelnych, dyskusję można uznać za zamkniętą 110 .

MPCM mówi o możliwości udziału w kolegium sędziowskim tylko mężczyzny (vir laicus). Wynika to nie tylko $z$ milczenia normy o kobiecie, ale także $\mathrm{z}$ wyraźnego wymienienia mężczyzny $\mathrm{w} n$. V, § 1 i w n. VII, pcdczas gdy o kobiecie jest mowa tylko przy funkcji notariusza $\mathrm{w} \mathrm{n}$. VI.

107 Por. Roberti F., De processibus, t. I, In Civitate Vaticana 1956, wyd. 4, s. $236-239$.

168 Gordon I., De nimia processuum matrimonialium duratione, s. 517-518.

109 Swiadczy o tym fakt, że Normy dla trybunałów międzydiecezjalnych lub regionalnych albo międzyregionalnych, wydane dnia 28 grudnia 1970 r. przez Sygnaturę Apostolską, a opublikowane w 1971 r. przez Sygnaturę w Drukarni Watykańskiej, w szczególe dotyczącym kapłaństwa sędziów kościelnych różnią się od oficjalnego tekstu tych Norm, opublikowanego w AAS 63 (1971), gdzie na s. 488, w art. 6, n. 1 czytamy o sędziach kościelnych: "sint ordinarie dignitate sacerdotali aucti”. Otóż we wcześniejszym tekście brakowało „ordinarie”.

110 Tak sądzą: Gordon I., De m.p., s. 191-192; Bernardini E., dz. cyt., s. 42; Bersini F., dz. cyt., s. 22; Regatillo E., dz. cyt., s. 636, który wskazuje na pewne precedensy tej decyzji. Pius XI powierzył sprawy separacji małżeńskiej trybunałom cywilnym włoskim. 
Wykluczenie kobiety od sprawowania funkcji sędziego kościelnego jest pociągnięciem niezrozumiałym i, jak twierdzą niektórzy, dyskryminującym. Trudno bowiem podać na jego uzasadnienie obiektywną rację. Skoro bariera kan. 118 Kodeksu Prawa Kanonicznego, który stanowił, że „sami duchowni mogą otrzymać kościelną władzę jurysdykcyjną”, została przełamana, dlaczego różnicę płci uczyniono zasadą wykluczającą kobiety od sądzenia spraw małżeńskich, które przecież są im tak bliskie.

Trudno zgodzić się $\mathrm{z}$ argumentem Gordona, który mówi: „Wykluczenie to, by ominąc inne racje, łatwo zrozumieć. Byłoby to bowiem za dużo, gdyby Ustawodawca dopuścił do funkcji dotąd zarezerwowanej kapłanom, nie tylko diakonów i świeckich mężczýzn, ale także i kobiety" 111 .

$\mathrm{Z}$ całej bardzo bogatej i niekiedy burzliwej dyskusji na ten temat 112 wynika, że sprawa poruszyła opinię publiczną i wymaga jakiegoś rzeczowego wyjaśniania. Nie podejmuję się wprawdzie dawać takiego wyjaśniania, ale wydaje się, że należy go szukać w połączeniu, jakie istnieje między funkcją rządzenia w Kościele a kapłaństwem. Jeśli kapłaństwo jest niedostępne dla kobiet, to niedostępna powinna też być i jurysdykcja kościelna, ściśle przecież z kapłaństwem związana. W ten sam sposób, tylko odwrotnie rozumując, można wytłumaczyć, dlaczego udostępniono stanowiska sędziów kościelnych świeckim mężczyznom.

Niezależnie od argumentów tłumaczących aktualne i obowiązujące w tym względzie ustawodawstwo, cała sprawa podyktowana jest raczej względami zwyczajowymi niż rzeczywistą niemożliwością, której przecież przeczą fakty historyczne ${ }^{113}$.

MPCM zastrzegając dla mężczyzn funkcję sędziowską, czyni jeszcze dalsze ograniczenie, a mianowicie, że do kolegium sędziowskiego musi wchodzić dwóch duchownych, a tylko jeden świecki mężc z y z n a.

Tak jak w poprzednim wypadku uczyniono ustępstwo od zasady kapłaństwa, obowiązującej mocą Kodeksu, w trybunałach kościelnych przez wprowadzenie do grona sędziów diakonów i świeckich mężczyzn, tak obecnie, przepis o obecności tylko jednego świeckiego mężczyzny w kolegium świadczy o podtrzymaniu przez Ustawodawcę, chociaż w osłabionej formie, tejże zasady kapłaństwa ${ }^{114}$.

111 Gordon I., De m.p., s. 193.

112 Obszerniejsze naświetlenie tego problemu, w formie wypowiedzi ankietowych, nie pozbawionych czasem przesady, ale też cechujących się niekiedy dobrą argumentacją teologiczną i prawną, można znaleźć w Ius Canonicum, vol. XII, n. 23 (1972) $189-238$.

113 Mam tu na myśli nieliczne wprawdzie, ale stwierdzone fakty przekazywania niektórym przełożonym zakonnym, kobietom, jurysdykcji kościelnej. Por. Alvarez-Menendez S., De utraque potestate ordinis et iurisdictionis sive laicis sive feminis de iure condendo concedenda vel minus, W: Angelicum 3-4 (1972) 387-390. 114 Di Jorio O., dz. cyt., s. 10-11; Gordon I., De m.p., s. 189-190. 
Nie trudno się też doszukać w tym przepisie chęci zabezpieczenia trybunałów kościelnych przed ich zmajoryzowaniem przez świeckich ${ }^{\mathbf{1 1 5}}$.

Nie ulega wątpliwości, że skoro świeccy mogą być sędziami kościelnymi wraz z duchownymi, to ustawodawstwo kościelne mogłoby powierzyć rozstrzyganie spraw małżeńskich samym tylko sędziom świeckim. W praktyce, zważywszy wielość zajęć duszpasterskich, którymi są obciążeni duchowni, mogłoby to doprowadzić do całkowitego przekreślenia zasady kapłaństwa, którą MPCM chce najwyraźniej zachować.

Świecki mężczyzna może zostać mianowany sędzią, jednak nie może w kolegium pełnić funkcji przewodniczącego. Ograniczenie to wynika stąd, że przewodniczącym kolegium może być tylko oficjał lub wiceoficjał, a w stosunku do tych urzędów wymaga się nadal kapłaństwa jako warunku nominacji (kan. 1573, § 4), gdyż przepis kan. 1573, § 4 nie uległ w MPCM zmianie ${ }^{116}$. Sądzę, że ograniczenie to nie dotyczy jednak funkcji ponensa, jak twierdzi G or d on ${ }^{117}$, gdyż zgodnie $\mathrm{z}$ kan. 1584 i art. 22 Instrukcji Provida przewodniczący ma ich wyznaczyć spośród kolegium (de iudicibus collegii), do którego przecież świeccy już należą.

Udział sędziów świeckich w procesie małżeńskim jest dopuszczalny w trybunałach pierwszej i drugiej instancji. To wyraźne wyszczególnienie dwóch instancji wskazuje, że świeccy nadal nie mają dostępu do trybunałów trzeciej instancji, zwłaszcza zaś do Roty Rzymskiej i Sygnatury Apostolskiej, a z trybunałów krajowych do Roty Hiszpańskiej. Wskazuje na to również sam początek n. V, § 1 MPCM, gdzie jest mowa tylko o trybunale diecezjalnym i regionalnym ${ }^{118}$. Nie wyklucza się jednak udziału świeckich $\mathrm{w}$ trybunałach drugiej instancji, rozpatrujących czasem sprawy $w$ trzeciej instancji mocą specjalnego zlecenia ${ }^{119}$.

$\mathrm{Z}$ tekstu normy wynika też, że powołanie diecezjalnego trybunału kolegialnego jest możliwe tylko tam, gdzie nie istnieje trybunał regionalny, do którego w takim wypadku należałoby sprawę odesłać 120.

Zezwolenia na powołanie kolegium sędziowskiego z udziałem świeckiego mężczyzny $\mathrm{i}$ to zarówno $\mathrm{w}$ trybunale diecezjalnym, jak i regionalnym, udziela Konferencja Biskupia tego terytorium, na którym znajduje się trybunał.

Zezwolenie to może być dane na stałe, gdyż norma nie zawiera pod

115 De Diego - Lora C., La reforma, s. 128-130.

116 Flatten H., dz. cyt. s. 7; Gordon I., De m.p., s. 193.

117 Gordon I., De m.p., s. 193.

118 Cabreros de Anta M.. dz. cyt., s. 239.

119 Flatten H., dz. cyt., s. 7; Gordon I., De m.p., s. 193.

120 Komisja Rewizji Kodeksu Prawa Kanonicznego proponowala pewne ograniczenia $w$ powoływaniu trybunałów diecezjalnych $\mathrm{z}$ udziałem świeckich mężczyzn, żądając, by $w$ wypadku niemożliwości ukonstytowania $w$ diecezji kolegium złożonego $\mathrm{z}$ trzech duchownych, starano się najpierw o powołanie trybunału regionalnego Zob. Communicationes 2 (1970) 189. 
tym względem żadnego ograniczenia. O zezwolenie zwraca się do Konferencji biskup diecezjalny lub biskup moderator trybunału regionalnego i oni też po otrzymaniu zezwolenia mianują sędziów spośród świeckich ${ }^{121}$.

Zezwolenie Konferencji Biskupiej nie dotyczy więc żadnego „,nihil obstat" w stosunku do kandydatów na stanowisko sędziego spośród świeckich, jest dawane abstrahując od osób, które dobiera sobie, już według własnego uznania, biskup. Raz dane pozwolenie otwiera drogę do nominacji nie tylko jednego sędziego, ale tylu ilu jest potrzebnych do sprawnego funkcjonowania trybunału.

Interwencja Konferencji Biskupiej także w wypadku trybunałów regionalnych, tłumaczy się tym, że od r. 1970 Stolica Apostolska nie rezerwuje sobie już powoływania trybunałów regionalnych, lecz powierza to Konferencjom Biskupim, dla siebie zostawiając tylko „,nihil obstat" i zatwierdzenie erekcji ${ }^{122}$. Ponieważ trybunały regionalne mają charakter ponaddiecezjalny, ingerencja Konferencji Biskupiej nie może w tym wypadku dziwić.

Natomiast interwencja Konferencji Biskupiej przy nominacji sędziów diecezjalnych zdaje się ,zmniejszać spoistość prawną systemu organizacyjnego Kościoła" ${ }^{123}$.

Drugą wielką nowością, wprowadzoną do kodeksowych przepisów procesu małżeńskiego, przez MPCM, jest możliwość pow ołania w sprawach małżéskich trybunału jednoosobowego. Mówi o tym $\mathrm{n}$. V, $\S 2$.

Z możliwości tej można jednak korzystać pod określonymi warunkami.

Pierwszym $\mathrm{z}$ nich jest ten, że trybunał jednoosobowy można powołać tylko wówczas, gdy nie ma możliwości ukonstytuowania kolegium sędziowskiego, nawet $\mathrm{z}$ udziałem świeckiego mężczyzny.

Tak jak przy dopuszczeniu świeckich do trybunału kościelnego, tak i tutaj Ustawodawca posłużył się normą o charakterze pomocniczym, przy czym pomocniczość ta jest już drugiego stopnia, bo powołanie kolegium z udziałem świeckiego także miało charakter pomocniczy ${ }^{124}$.

Takie ustawienie sprawy prowokuje do dyskusji, który z trybunałów, kolegialny czy jednoosobowy, lepiej służy wymiarowi sprawiedliwości? Odsyłając w tej kwestii do literatury, gdyż dyskusja ta toczy się nie od dziś ${ }^{125}$, warto zauważyć, że Ustawodawca kościelny, przynajmniej w sprawach małżeńskich, wyraźnie woli trybunał kolegialny ${ }^{126}$.

\footnotetext{
121 Lefebvre C., Il motu proprio, s. 39.

122 Art. 2, § 1 Norm dla trybunatów regionalnych: AAS 63 (1972) 487.

123 De Diego - Lora C., La reforma, s. 132.

124 De Diego - Lora C., La reforma, s. 135.

125 Pieronek T., Normy ogólne, s. 116.

126 Di Jorio O., dz. cyt., s. 10-11; Del Amo Pachon L.. dz. cyt., s. 110.
} 
Trybunał jednoosobowy można powołać w yłąc znie w pierwszej instancji. Czyli innymi słowy nie może się powtórzyć sytuacja, którą sankcjonowały n. 3 i 23 Norm amerykańskich, gdzie sprawa małżeńska, osądzona $\mathrm{w}$ pierwszej instancji przez trybunał kolegialny, mogła być rozpatrywana w drugiej instancji przez sędziego jednoosobowego ${ }^{127}$. Jest to potwierdzeniem preferencji Ustawodawcy dla trybunału kolegialnego.

W każdym wypadku tworzenia trybunału jednoosobowego sędzia może być tylko duchowny, a więc, zgodnie z tym co powiedziano wyżej, kapłan lub diakon. Świeckim funkcji tej powierzać nie można, zaleca się natomiast, tam gdzie to możliwe, by sędzia jednoosobowy dobrał sobie do prowadzenia sprawy lawnika i audytora, ale tylko spośród świeckich mężczyzn.

I w tym wypadku wykluczenie kobiet jest niezrozumiałe, tym bardziej że, jak wiadomo, ławnik nie sprawuje jurysdykcji kościelnej.

Trybunał jednoosobowy musi być powołany za każdym razem $z$ osobna, do poszczególnych spraw małżéskich (singulis in casibus).

Flatten wprawdzie utrzymuje, że Konferencja Biskupia, która musi zawsze zezwolić na utworzenie trybunału jednoosobowego, mo'głaby dać pozwolenie stałe, a to w takim wypadku, kiedy w diecezji nie ma żadnej możliwości ukonstytuowania innego trybunału. Wówczas konieczność zwracania się za każdym razem po pozwolenie do Konferencji Biskupiej niweczyłaby cel MPCM, którym jest przyspieszenie $\mathrm{w}$ załatwianiu spraw małżeńskich ${ }^{128}$.

Takiej interpretacji przyjąć jednak nie można. Tekst normy jest wyraźny: w poszczególnych wypadkach, a określenie to w kanonistyce jest jednoznaczne. Wszyscy też inni autorzy przyjmują ścisłe tłumaczenie tej klauzuli 129 .

Del A mo jest nawet zdania, że wyrok wydany przez trybunał jednoosobowy, bez zezwolenia Konferencji Biskupiej do każdego wypadku z osobna, jest nieusuwalnie nieważny (kan. 1892, n. 1 i kan. 40) ${ }^{130}$.

Zezwolenia na trybunał jednoosobowy udziela Konferencja Biskupia.

O podobnym zezwoleniu mówiły już Normy amerykańskie (n. 3), nie precyzowały jednak sposobu jego udzielania. Obecnie MPCM w normie V, $\S 3$ ustala dwa takie sposoby, na które mógł zezwolić tylko Ustawodawca.

127 Pieronek T.. Normy postępowania w sprawach małżeńskich wydane przez Stolicę Apostolską dla diecezji Stanów Zjeđnoczonych, W: Prawo Kanoniczne 3-4 (1973).

128 Flatten H., dz. cyt., s. 9.

129 De Diego - Lora C., La reforma, s. 137; Cabreros de Anta M., dz. cyt., s. 242; Lefebvre C., Il motu proprio, s. 40; Bersini S., dz. cyt., s. 24; Gordon I., De m.p., s. 195.

130 Del Amo Pachon L., dz. cyt., s. 111. 
A więc obok normalnej drogi działania, przepisanej dla Konferencji Biskupiej w dekrecie Christus Dominus, w n. 38, mogą one wydawać zezwolenia dotyczące trybunałów kościelnych, albo:

1) poprzez specjalnie do tego powołaną Komisję, złożoną $\mathrm{z}$ kilku członków Konferencji, albo 2) poprzez jednego, delegowanego do tej czynności członka Konferencji.

Obydwa te sposoby bardzo ułatwią załatwianie wszelkich potrzebnych pozwolen. Możliwość delegowania władzy posiadanej w tym względzie przez Konferencje organom wyspecjalizowanym (komisji) albo któremuś $\mathrm{z}$ biskupów znających problemy sądownictwa kościelnego jest umożliwieniem przekazania tych spraw w fachowe ręce ${ }^{\mathbf{1 3 1}}$.

Sposób, w jaki Konferencja Biskupów chce wypowiadać się w tej sprawie, powinien być określony w jej statutach.

Gdyby Konferencja Biskupów, działając jako całość, albo poprzez komisję czy specjalnego delegata, odmówiła prośbie biskupa, zawsze w tych sprawach można złożyć rekurs do I sekcji Sygnatury Apostolskiej 132 .

MPCM przewiduje udział świeckich nie tylko na stanowisku sędziego głównego, ale zezwala też (w n. V, $\S 2$ i n. VI) na powierzenie im funkcji ławników i a udytorów, przy czym dotyczy to znowu tylko mężczyzn, oraz stanowiska notariusza, wymieniając dopiero tutaj wyraźnie także i kobiety.

Jeśli chodzi o ławników, to Kodeks Prawa Kanonicznego stoi na stanowisku, że „sędzia jednoosobowy w każdym procesie może sobie dobrać dwóch ławników jako swych doradców, musi ich jednak wybrać spośród sędziów synodalnych" (kan. 1575). Konieczność wyboru ławników spośród sędziów synodalnych przesądzała o tym, że nie mogli tej funkcji pełnić świeccy. Zadaniem ławników jest studiowanie akt i doradzanie sędziemu w procesie. Nie posiadają oni jednak jurysdykcji sądowej i nie tworzą wraz $\mathrm{z}$ sędzią trybunału kolegialnego, ani też sędzia nie jest skrępowany ich opinią i wyrok wydaje własną powagą ${ }^{133}$.

Wynika stąd, że zgodnie z MPCM świeccy mężczyźni mogą już być ławnikami w sądach kościelnych i to $\mathrm{w}$ trybunałach wszystkich stopni (n. VI MPCM), sam charakter doradczy tej funkcji nie ulega zmianie.

Rola audytora jest w trybunale nieco inna.

Kodeksowe prawo również zarezerwowało tę funkcję kapłanom, co było o tyle zrozumiałe, że zadaniem audytora jest wzywanie i przesłuchiwanie świadków, oraz dokonywanie innych czynności sądowych, zgodnie ze zleceniem sędziego głównego, co jest równoznaczne $\mathrm{z}$ wyko-

131 Cabreros de Anta M., dz. cyt., s. 243.

132 Gordon I., De m.p., s. 195.

133 Pieronek T., Normy ogólne, s. 103-105. 
nywaniem jurysdykcji. Audytor jednak, podobnie jak ławnicy, nie ma wpływu na wydawany wyrok ${ }^{134}$.

Udostępnienie tej funkcji mężczyznom świeckim jest więc kolejnym potwierdzeniem wyłomu, jakiego MPCM dokonało, przyznając świeckim możliwość sprawowania jurysdykcji kościelnej ${ }^{135}$.

Nominacji ławników dokonuje sędzia jednoosobowy, audytora natomiast, jeśli na stałe, to Ordynariusz, jeśli do określonej sprawy, oficjał ${ }^{136}$. Ponieważ ich udział w procesie może mieć pośredni wpływ na wyrok, o ich nominacji należy zawiadomić strony procesowe, by mogły zgłosić ewentualne zastrzeżenia ${ }^{137}$. Opinie ławników winien sędzia wziąc pod uwagę, jeśli zaś od nich odstępuje, wyrok ma zawierać racje, dla których sędzia opinie te odrzucił ${ }^{138}$.

Notariuszami mogły być kobiety juz według prawa kodeksowego, faktem jest jednak, że w praktyce przez wiele lat nie były do tej funkcji dopuszczane. Stosunkowo niedawno rozpowszechniła się praktyka mianowania na to stanowisko sióstr zakonnych. Właściwie więc nie zaszły $\mathrm{w}$ tej sprawie żadne zmiany, poza pozytywnym stwierdzeniem Ustawodawcy, że kobiety mogą pełnić tę funkcję.

Wreszcie n. VII MPCM omawia kwalifikacje moralne i zawodowe, jakie powinni posiadać świeccy, powoływani do pracy w trybunałach kościelnych.

Jako kwalifikacji moralnych norma wymaga, by osoby te odznaczały się wiarą katolicką i dobrymi obyczajami.

Wśród kwilifikacji fachowych wymienione są: wiedza kanoniczna, a w stosunku do kandydatów na sędziów, na pierwszym miejscu praktyka sądowa.

Szkoda, że określając kwalifikacje fachowe nie precyzuje ich bliżej, ale wydaje się, że, przez analogię z przepisami kodeksowymi odnoszącymi się do wymienionych w MPCM funkcji, minimum tych kwalifikacji stanowi rzeczywista biegłość w prawie kanonicznym, nie koniecznie stopień akademicki.

$\mathrm{Na}$ koniec tego rozdziału jedno pytanie. Czy świeccy mogac dziś pełnić w trybunałach kościelnych obowiązki rzecznika sprawiedliwości i obrońcy węzła małżeńskiego?

MPCM milczy na ten temat zupełnie.

Ze względu na warunek kapłaństwa, jaki stawiał Kodeks w kan. 1589, $\S 1$ do nominacji na te urzędy, zgodnie z tym, co mówi wstęp do MPCM:

134 Pieronek T., Normy ogólne, s. 120-124.

135 Cabreros de Anta M., dz. cyt., s. 243.

136 De Diego - Lora C., La reforma, s. 142; Gordon I., De m.p., s. 197.

137 De Diego - Lora C., La reforma, s. 140.

138 Lefebvre C., Il.motu proprio, s. 41. 
„firmis itaque manentibus reliquis normis canonicis circa processus", należy uznać, że droga do tych urzędów pozostała przed świeckimi zamknięta.

Postulat zaś, jaki wysuwają autorzy, by w szczególnych wypadkach Stolica Apostolska bezpośrednio, lub poprzez Konferencje Biskupów mianowała rzecznikiem sprawiedliwości lub obrońcą węzła diakonów lub nawet świeckich mężczyzn ${ }^{139}$, bywa rzeczywiście spełniany ${ }^{140}$.

\section{APELACJA}

VIII. § 1. Od pierwszego wyroku, orzekajacego nieważność małżeństwa, obrońca węzła obowiazzany jest odwołać się w przewidzianym przez prawo terminie do wyższego trybunatu. Gdyby się $w$ tym zaniedbat, ma go do tego przynaglić przewodniczacy (trybunału kolegialnego) lub sędzia trybunatu jednoosobowego.

§. 2. W trybunale drugiej instancji obrońca węzła winien przedstawić uwagi, by wyrazić swoje stanowisko na temat: czy ma jakieś zastrzeżenia lub nie co do decyzji wydanej $w$ pierwszej instancji. Jeżeli kolegium uzna to za wskazane, ma zażądać od stron lub ich adwokatów odpowiedzi na te uwagi obrońcy.

§ 3. Po przestudiowaniu wyroku i rozważeniu uwag obrońcy węzła oraz - gdy sie tego domagano $i$ byty przedstawione - odpowiedzi stron lub adwokatów, kolegium wydanym przez siebie dekretem zatwierdza decyzje pierwszej instancji, ewentualnie dopuszcza sprawe do zwyczajnego rozpatrzenia $w$ drugiej instancji. W pierwszym wypadku, jeżeli nikt nie zgłasza rekursu $i$ uptynie dziesięć dni od ogłoszenia dekretu, przystuguje matżonkom - nie zwiazanym innymi przeszkodami prawo zawarcia nowego mał̇̇eństwa.

IX. § 1. Od dekretu kolegium, zatwierdzajacego wyrok pierwszej instancji, maja możność wniesienia rekursu do wyższego trybunału zarówno obrońca, jak i strona, która czułaby się pokrzywdzona. Rekurs trzeba zgłosić $w$ ciagu dziesięciu dni od dnia ogłoszenia dekretu. Warunkiem wszakże zgłoszenia rekursu jest powołanie się na nowe i poważne argumenty, które jednak winny być pod ręka. Takie argumenty należy przedstawić trybunałowi trzeciej instancji $w$ ciagu miesiaca od zgłoszenia rekursu.

§. 2. Obrońca węzła trzeciej instancji może - wystuchawszy zdania przewodniczacego trybunału - nie podtrzymać rekursu. W tym wys. $113-114$.

139 Cabreros de Anta M., dz. cyt., s. 244; Del Amo Pachon L., dz. cyt.

140 Faktycznie Stolica Apostolska mianowała w 1970 r. świeckiego mężczyznę obrońcą węzła małżeńskiego w Münster w N.R.F. Zob. Pontificia Universitas Gregoriana, Elenchus Participantium Cursui Renovationis Canonicae pro Iudicibus et Tribunalium Administris, Notificatio 3a, 18. X. 1971. 
padku trybunat stwierdza zakończenie procesu. Jeżeli natomiast rekurs zgłasza strona, trybunat - rozważywszy przedstawione argumenty $w$ ciagu miesiaca od założenia rekursu albo odrzuca rekurs dekretem, albo dopuszcza sprawe do zwyczajnego rozpatrzenia $w$ trzeciej instancji.

Jednym ze sposobów, przy pomocy którego MPCM niewątpliwie osiągnie swój cel, to jest skrócenia w czasie prowadzenia spraw małżeńskich w sądach kościelnych, jest zmiana przepisów dotyczących apelacji.

Postulaty $\mathrm{w}$ tej dziedzinie szły bardzo daleko, poprzez zniesienie obowiązku apelacji, nałożonego kan. 1986 na obrońcę węzła małżeńskiego, aż do zniesienia apelacji w ogóle. Uważano, że ta właśnie faza procesu bardzo go przedłuża ${ }^{141}$.

Ustawodawca w normie VIII, § 1 MPCM zatrzymuje jednak obowiązek apelacji obrońcy węzła, od pierwszego wyroku orzekającego nieważność małżeństwa i powtarza treść kan. 1986, dosłownie zaś art. 212, § 2 Instrukcji Provida, z małym uzupełnieniem dotỵczącym sędziego jednoosobowego. $\mathrm{Z}$ \& 1 normy VIII nie wynika więc żadna istotna różnica $\mathrm{w}$ stosunku do prawa kodeksowego.

Dopiero $\S 2$ dokonuje bardzo poważnej zmiany, tak w stosunku do pojęcia apelacji, jak też $\mathrm{w}$ odniesieniu do roli obrońcy węzła w procesie małżeńskim i zasady równości stron w procesie.

Najpierw pojęcie a pelacji. W ścisłym znaczeniu przez apelację należy rozumieć odwołanie się od niższego sędziego, który wydał wyrok, do wyższego trybunału, po to, by drogą nowego procesu rozpatrzył sprawę i nowym wyrokiem zatwierdził lub odrzucił orzeczenie niższego trybunału. Tymczasem według n. VIII, § 2 MPCM odwołanie się obrońcy węzła małżeńskiego do trybunału apelacyjnego, nie koniecznie powoduje takie skutki, w szczególności zaś, tylko w niektórych wypadkach prowadzi do normalnego procesu w drugiej instancji i do wydania normalnego wyroku. Zatwierdzenie wyroku pierwszej instancji może nastąpić przez dekret trybunału kolegialnego drugiej instancji, który nie przeprowadził ex novo całego procesu, a oparł swą decyzję na ocenie obrońcy węzła i na sumarycznym zbadaniu akt sprawy. Wszystko to wskazuje, że w tym wypadku należy mówić o nowym niespotykanym dotychczas $\mathrm{w}$ kanonistyce pojęciu apelacji ${ }^{142}$.

Zmianie ulega też rola obrońcy węzła w apelacyjnej fazie procesu małżeńskiego, w konsekwencji i w całym procesie małżeńskim.

141 Gordon I., De nimia processuum matrimonialium duratione, s. 725.

142 Del Amo Pachon L., dz. cyt., s. 116-118; Souto J., dz. cyt., s. 101; De Diego - Lora C., La reforma, s. 152. 
Kan. 1968, n. 3 zobowiązywał obrońcę do pisania uwag ,przeciwko nieważności małżeństwa”, a nadto do ,przytaczania wszystkiego, co uzna za pożyteczne do obrony małżeństwa". MPCM stawia sprawę inaczej, zobowiązuje obrońcę, by wypowiedział się, ,czy ma coś do przeciwstawienia” wyrokowi, od którego apeluje ,,,czy też nie” (n. VIII, § 2 MPCM), daje zatem obrońcy możliwość wypowiedzenia się pro rei veritate. Oznacza to wprowadzenie do normy ustawodawczej nauki głoszonej już przez pap. Piusa XII w 1944 r. ${ }^{143}$, przyznającej obrońcy swobodę działania i możliwość współpracy z całym trybunałem, celem wykrycia podczas procesu prawdy obiektywnej ${ }^{144}$.

MPCM w normie VIII, § 2 narusza zasadę równouprawnienia, czy równości stron $\mathrm{w}$ procesie małżeńskim. Przewiduje ona, że jeśli wyrok trybunału pierwszej instancji sprzyja nieważności małżeństwa, postępowanie w drugiej instancji, po apelacji obrońcy węzła małżeńskiego, przybiera postać procesu skróconego, jeśli natomiast wyrok pierwszej instancji orzeka ważność mał̇żeństwa, stronie pokrzywdzonej tym wyrokiem pozostaje do dyspozycji tylko normalne, dotychczasowe postępowanie w drugiej instancji $\mathbf{1 4 5}$.

Po zasygnalizowaniu tych kilku nie małej wagi kwestii, poruszonych przez n. VIII, § 2 MPCM i wymagających w przyszłości poważniejszego studium, przejdę do omówienia tekstu tych norm.

W drugiej instancji zostaje wprowadzony nowy, skrócony sposób postępowania.

Polega on na tym, że po przesłaniu akt sprawy pierwszej instancji do trybunału drugiej instancji, pierwszym, który zasiada do ich studiowania jest obrońca węzła małżeńskiego drugiej instancji 146. Jego zadaniem jest sporządzić uwagi (animadversiones) na temat decyzji, wydanej $\mathrm{w}$ pierwszej instancji i przedstawić je kolegium, złożonemu z trzech sędziów, które ukonstytuowało się w drugiej instancji zaraz po wniesieniu apelacji.

Norma VIII, § 2 nie mówi wprawdzie, że obrońca węzła pisze swoje uwagi po przestudiowaniu wyroku i akt sprawy pierwszej instancji, jest to jednak rzeczą pewną, iż w swoich uwagach nie może on się oprzeć jedynie na wyroku, jest on bowiem $\mathrm{z}$ natury rzeczy skrótowym ujęciem sprawy i chociażby nawet był słuszny, to przecież nie zawsze wystar-

143 AAS 36 (1944) 285.

144 Di Jorio O., dz. cyt., s. 15; Lefebvre C., De motu proprio, s. 415; Filipiak B., De motu proprio "Causas matrimoniales", W: Ephemerides Iuris Canonici 3-4 (1971) Fedele P., A proposito del motu proprio "Causas matrimoniales" sui processi canonici di nullità di matrimonio, W: Ephemerides Iuris Canonici 3-4 (1971) S. 440; Regatillo E., dz. cyt., s. 638-639.

145 Cabreros de Anta M., dz. cyt., s. 246; De Diego - Lora C., La reforma, s. $144-151$.

146 Di Jorio O., dz. cyt., s. 15. 
czająco ujawnia słabe strony procesu, które mogłyby posłużyć obrońcy za wystarczający materiał do ewentualnej polemiki.

Po przedstawieniu uwag przez obrońcę węzła, przystępuje do pracy kolegium, które, jeśli to uważa za stosowne, może zarządać uwag sporządzonych przez strony procesowe, lub ich adwokatów. Czynność ta jednak nie jest obowiązkowa i zależy od decyzji kolegium. MPCM nie nakłada na kolegium obowiązku wysłuchania stron i ich adwokatów prawdopodobnie dlatego, że $\mathrm{w}$ sprawach całkowicie jasnych byłoby to zbyteczne i przedłużałoby proces. Normalnie sędziowie drugiej instancji winni się zwracać o takie uwagi wówczas, gdy powstają trudności z zatwierdzeniem pozytywnego wyroku pierwszej instancji. Kolegium, w wypadku gdy żąda uwag, może też określić, w jakim czasie winny one być dostarczone trybunałowi. Oznacza to, że został zniesiony przywilej obrońcy węzła małżeńskiego, zawarty w kan. 1969, n. 2 i 3, dzięki któremu mógł się on wypowiadać w procesie zawsze jako ostatni. Zniesienie tego przywileju wydaje się jednak dotyczyć tylko skróconej formy procesu drugiej instancji, w innych wypadkach dawna zasada pozostaje W mocy ${ }^{147}$.

Drugim zadaniem kolegium - o którym mówi już n. VIII, § 3 MPCM - jest przestudiowanie wyroku pierwszej instancji i rozważenie uwag obrońcy węzła, ewentualnie uwag stron lub ich adwokatów, oraz wydanie dekretu zatwierdzającego wyrok pierwszej instancji, lub dopuszczającego sprawę w drugiej instancji do zwyczajnego rozpatrzenia.

Jest rzeczą charakterystyczną, że norma VIII, § 3 mówiąc o materiale, który kolegium ma przestudiować przed wydaniem dekretu, używa określenia „visa sententia et perpensis animadversionibus defensoris vinculi, necnon, si exquisitae et datae fuerint, partium earumve patronorum", zamiast krótszego, a obejmującego wszystkie wyżej wymienione pisma określenia „visis actis”.

Trudno przyjąć, by Ustawodawca $\mathrm{w}$ tak ważnym $\mathrm{z}$ punktu widzenia procesowego określeniu był dowolny i niepotrzebnie wyliczał $\mathrm{w}$ szczegółach to, co kolegium przed podjęciem decyzji ma przeanalizować, skoro w określeniu ,,acta" mógł zawrzeć to wszystko.

Celem reformy procesu małżeńskiego było przede wszystkim przyspieszenie procesu, stąd też wydaje się - że Ustawodawca nie żąda, by kolegium $\mathrm{w}$ drugiej instancji studiowało akta, tym bardziej że studiował je już obrońca węzła małżeńskiego drugiej instancji, żąda jedynie, by $\mathrm{w}$ oparciu o studium wyroku pierwszej instancji i ewentualnych uwag stron i adwokatów wydało decyzję.

Nie zapominajmy, że studium tego mają dokonać trzy osoby i gdyby im przyszło zapoznać się z całością akt sprawy, zreformowany proces

147 Lefebvre C., De motu proprio, s. $417-419$. 
nie wiele zyskiwałby $\mathrm{w}$ czasie $\mathrm{w}$ stosunku do obecnego, gdy np. $\mathrm{w}$ drugiej instancji nie zgłasza się nowych dowodów; a do takich właśnie spraw należą te, które uzyskują pozytywny wyrok w pierwszej instancji.

Nie przeczę, że w takim ustawieniu sprawy na obrońcę węzła drugiej instancji spada wielka odpowiedzialność sumiennego spełnienia obowiązku, gdyż zaniedbanie z jego strony, zwłaszcza gdyby się zbiegło ze słabo opracowanym wyrokiem pierwszej instancji, może doprowadzić do mylnych decyzji.

Nie ma zresztą żadnych przeszkód, by w wypadku wątpliwości, członkowie kolegium drugiej instancji nie mogli sięgnąc po akta, czy nawet zabrać się do ich studiowania; nie sądzę jednak, by na podstawie normy VIII, § 3, studiowanie akt sprawy należało traktować jako obowiązującą regułę ogólną.

Mimo całej tej argumentacji trzeba jednak zająć inne stanowisko. Trudno bowiem pojąć, by jakiekolwiek kolegium, wydając decyzję, a mając do dyspozycji akta sprawy, mogło się oprzeć na opiniach z drugiej ręki. Trzeba także zważyć, że często niestety wyroki pierwszej instancji są redagowane nie najlepiej. Kolegium zaś - mówi Flatten - zatwierdzające wyrok, musi uzyskaé pewność o jego słuszności, do czego potrzebne jest przekonanie, że małżeństwo jest rzeczywiście nieważne, że jest nieważne $\mathrm{z}$ tytułu uznanego $\mathrm{w}$ wyroku i że motywy uzasadniające wyrok, a przynajmniej jeden $\mathrm{z}$ nich i zasadniczy, jest przytoczony trafnie ${ }^{148}$. Inaczej nieco argumentując, opinię tę przyjmują $i$ inni autorzy 149 .

Skrócone postępowanie, które kończy się d ekretem kolegi u m drugiej instancji, zatwierdzającym wyrok pierwszej instancji, ma zastosowanie tylko $\mathrm{w}$ wypadku apelacji obrońcy węzła małżeńskiego od pozytywnego wyroku, wydanego $\mathrm{w}$ pierwszej instancji.

Przez pierwszą instancję należy tu rozumieć nie tyle trybunał pierwszego stopnia, ile raczej pierwszy pozytywny wyrok wydany bądź przez trybunał pierwszego stopnia, bądź przez trybunał apelacyjny wprawdzie, ale orzekający jako trybunał pierwszej instancji ${ }^{150}$. Może to mieć miejsce łatwo wówczas, gdy trybunał apelacyjny dopuści nowy tytuł nieważności małżeństwa i na jego podstawie uzna nieważność małżeństwa.

Postępowaniem skróconym nie można się natomiast posłużyć:

a) po apelacji od negatywnego wyroku;

b) po równoczesnej apelacji od pozytywnego wyroku pierwszej instancji, złożonej przez obrońcę węzła małżeńskiego i stronę, dla której wyrok ten był niekorzystny;

148 Flatten H., dz. cyt., s. 13.

149 Del Amo Pachon L., dz. cyt., s. 123-124; Lefebvre C., De motu proprio, s. 420 ; Di Jorio O., dz. cyt., s. 15.

150 Di Jorio O., dz. cyt., s. 13; Lefebvre C., De motu proprio, s. 415. 
c) po apelacji obrońcy węzła małżeńskiego od pozytywnego wyroku, poprzedzonego jednym lub dwoma wyrokami negatywnymi 151.

Pierwszy $\mathrm{z}$ tych wypadków nie budzi wątpliwości, wobec jasnego w tym względzie tekstu normy VIII, § 1 i 2 MPCM.

W wypadku apelacji złożonej równocześnie przez obrońcę węzła małżeńskiego i poszkodowaną pozytywnym wyrokiem stronę, nie można stosować postępowania skróconego, gdyż MPCM nie przewiduje go w wypadku apelacji strony procesowej ${ }^{152}$. Ponadto za taką interpretacją przemawia aktualne stanowisko Roty Rzymskiej 153, a co więcej, proces skrócony ograniczałby swobodne korzystanie $\mathrm{z}$ praw, przysługujące stronie poszkodowanej wyrokiem ${ }^{154}$. Ograniczenie takie wynikałoby chociażby z niemożliwości przedstawienia nowych dowodów, bo takiego postępowanie skrócone nie przewiduje.

Trzeci wypadek szeroko analizuje Di J orio. Powołuje się przede wszystkim na oczywiste znaczenie słów rozważanych w tekście i kontekście (kan. 18). MPCM posługuje się takimi terminami jak: „tribunal secundae instantiae” (n. VIII, § 2), ,examen secundi gradus” (n. VIII, $\S 3$ ), wyrok zaś, od którego apelacja pozwala na postępowanie skrócone, określa: decyzją wydaną ,in primo gradu” (n. VIII, § 2), lub decyzją „primi gradus” (n. VIII, § 3 ; n. IX, § 1). Zwraca również uwagę, że güyby można stosować proces skrócony po jakimkolwiek wyroku pozytywnym, przekreśliłoby to wartość kan. 1014, stanowiącego o przychylncści prawa dla ważności małżeństwa, dokąd jego nieważność nie zostanie udowodniona. W konkluzji stwierdza, że tylko po wyroku pierwszej instancji, orzekającym nieważność małżeństwa, może istnieć domniemanie jego nieważności. Takie domniemanie jest nie do przyjęcia, gdy pozytywny wyrok poprzedziły negatywne. „Nie jest rzeczą wskazaną stwierdza dalej Di Jorio - by, skoro wielu sędziów doszło do sprzecznych wyroków na drodze formalnego i zwykłego procesu, pozwolić, by inni sędziowie rozstrzygnęli ten spór definitywnie drogą prostszego procesu zatwierdzającego: byłoby to nienależnym faworyzowaniem nieważności" ${ }^{155}$.

L ef e bvre podaje jeszcze jeden ciekawy argument za takim rozumieniem MPCM, a mianowicie, że Sekretariat Stanu powiadomił dnia 29 lutego 1972 r., że Ojciec św. nie udziela dyspensy od pozytywnego

151 Di Jorio O., dz. cyt., s. 13.

152 Cabreros de Anta M., dz. cyt., s. 246.

153 Dekret Roty Rzymskiej c. Bejan, z dnia 11 grudnia 1971 r. Przytaczam za Lefebvre C., De motu proprio, s. 416.

154 Di Jorio O., dz. cyt., s. 14.

155 Di Jorio O., dz. cyt., s. 14. Przeciwną opinię mają w tej sprawie Ferrata J. - Napoleoni H., dz. cyt., s. 8. 
wyroku drugiej instancji w wypadku, gdy pierwszy wyrok pozytywny poprzedziły negatywne ${ }^{\mathbf{1 5 6}}$.

Kolegium drugiej instancji, po zapoznaniu się z wyrokiem pierwszej instancji, z uwagami obrońcy węzła i ewentualnie stron i ich adwokatów, może natychmiast przystąpić do wydania dekretu zatwierdzającego wyrok pierwszej instancji, lub kierującego sprawę na drogę zwyczajnego procesu.

Bardzo rzadko - twierdzi Di J orio - uwagi stron, względnie ich adwokatów będą tu potrzebne. O ile jednak zaszłaby ich potrzeba, wskazywałoby to raczej, że rozstrzygnięcie sporu winno nastąpić na drodze zwyczajnego procesu. W każdym razie uwagi te nie dopuszczają już repliki ${ }^{157}$.

Dekret wydany przez kolegium, ponieważ ma charakter dekretu posiadającego moc orzeczenia stanowczego (kan. 1880, n. 6), winien zawierać motywację in iure et in facto, przynajmniej sumaryczną ${ }^{158}$.

Natura tego dekretu jest dyskusyjna. Di Jorio wychodząc z założenia, że postępowaniu skróconemu brak jest kontradykcyjności, uważa, że dekret ten przybiera postać zarządzenia administracyjnego, będącego aktem jurysdykcji dobrowolnej ${ }^{159}$. L e f e b v re natomiast, który widzi w procesie skróconym przynajmniej niedoskonałą kontradykcyjność, jest zdania, że mamy tu do czynienia $\mathrm{z}$ dekretem sądowym ${ }^{160}$.

Do wydania dekretu zatwierdzającego wyrok pierwszej instancji sęđiziowie wchodzący w skład kolegium winni mieć moralną pewność co do nieważności małżeństwa ${ }^{\mathbf{1 6 1}}$. Sędziowie przed naradą nie są zobowiązani przygotować wniosków na piśmie, gdyż MPCM nigdzie nie

156 Lefebvre C., De motu proprio, s. 416.

157 Di Jorio O., dz. cyt., s. 15.

158 Lefebvre C., De motu proprio, s. 420, który również tutaj powoluje się na dekret rotalny c. Bejan z dn. 11 grudnia 1971 r.; Cabreros de Anta M., dz. cyt., s. 246; Del Amo Pachon L., dz. cyt., s. 123; De Diega - Lora C., La reforma, s. 167.

159 Di Jorio O., dz. cyt., s. 16: „At, per se, processus brevior non praevidet commutationem scripturarum, ideo praescindere potest a contradictório, et quatevus praescindat, induit naturam provisionis administrativae manantis ex auctoritate iudiciaria, seu quid simile ad ea quae vocantur 'provvedimenti in camera di consiglio e di volontaria giurisdizione'..."

160 Lefebvre C., De motu proprio, s. 421: „De natura autem istius decreti determinandum est istud non videri 'mera provisio administrativa auctoritatis iudiciariae, similis ad ea quae vocantur provvedimenti in camera di consiglio e di volontaria giurisdizione'. Profecto, deficere videtur contradictorium saltem perfectum, at negandum non est contradictorium quoddam inperfectum, cum petitae fuerint animadversiones vinculi Defensoris forte contradicentes et impugnatae a contra - observationibus partium et patronorum: haec contentio quae excludi nequit vetat applicationem can. $201 \S 3$ et ostendit decretum non esse mere administrativum sed remanere iudiciale". $\mathrm{Na}$ ten temat zob. Molteni G., Sulla natura del Decreto ex $n$. VIII, \& 3 del Motu proprio „Causas matrimoniales”, W: Il Diritto Ecclesiastico, t. 83 (1872) 1-20.

161 Del Amo Pachon L., dz. cyt., s. 123-124. 
nakłada na nich takiego obowiązku. Jeśli jednak stosują tę praktykę, należy zachować postanowienie kan. 1871 , 33 , który wymaga, by pisemne wnioski sędziowskie były zachowane w tajemnicy ${ }^{162}$.

Jeśli kolegium dekretem zatwierdzi wyrok pierwszej instancji, a nikt nie zgłasza rekursu (o którym będzie mowa za chwilę), małżonkowie, o ile nie są związani innymi przeszkodami, mają prawo zawarcia nowego małżeństwa, po upływie dziesięciu dni od ogłoszenia dekretu (n. VIII, $\S 3)$.

Prawo małżonków do zawarcia nowego małżeństwa powstaje w chwili, kiedy, $\mathrm{z}$ braku rekursu $\mathrm{w}$ przepisanym terminie, pozytywny wyrok pierwszej instancji, zatwierdzony dekretem drugiej instancji, przechodzi w stan rzeczy osądzonej, specyficzny dla spraw małżeńskich ${ }^{163}$.

Jeśli natomiast kolegium dekretem skieruje sprawę do zwyczajnego rozpatrzenia, od dekretu tego, ponieważ nie posiada on mocy orzeczenia stanowczego, nie przysługuje żaden rekurs ${ }^{164}$.

Norma IX, § 1 MPCM wprowadza dwie ważne nowości:

a) nie zezwala obrońcy węzła małżeńskiego na tzw. apelację pro conscientia;

b) ustala ścisłe terminy i warunki rekursu do trzeciej instancji.

Kan. 1987 Kodeksu zezwalał obrońcy węzła na apelację podyktowaną głosem własnego sumienia. Przysługiwała mu ona nawet po dwóch wyrokach stwierdzających nieważność małżeństwa. MPCM zrównało obrońcę węzła ze stronami procesowymi, zezwalając mu na rekurs, ściśle jednak określony w czasie i oparty na dowodach, nie zaś na przekonaniu własnym ${ }^{165}$.

Zachodzi jednak pytanie, czy obrońca węzła całkowicie stracił prawo do apelacji pro sua conscientia? Wydaje się, że nie ma ona zastosowania tylko przy postępowaniu skróconym, co można uzasadnić tym, że dopuszczając do takiego procesu domniemywa się nieważność małżenstwa i dlatego zmniejsza się gwarancje procesowe, do których należy apelacja pro conscientia.

Co do terminów i warunków rekursu do trzeciej instancji warto zwrócić uwagę, że rekurs można wnosić w ciągu dziesięciu dni (por. kan. 1881 i art. $215, \S 1$ oraz $188, \S 2$ ), ważne zaś i nowe argumenty trzeba przedstawić trybunałowi trzeciej instancji, w ciągu miesiąca od dnia ogłoszenia dekretu, przy czym argumenty te muszą być niejako pod ręką, by przy wstępnej ich ocenie sędzia mógł sobie wyrobić zdanie o ich

162 Nie ulega wątpliwości, że przygotowanie pisemnych wniosków lepiej służy wymiarowi sprawiedliwości, zmusza bowiem do lepszego przestudiowania sprawy. 163 Di Jorio O., dz. cyt., s. 15 i 17, nazywa to „quasi-res iudicata".

164 Del Amo Pachon L., dz. cyt., s. 124; Di Jorio O., dz. cyt., s. 17; Cabreros de Anta M., dz. cyt., s. 247.

165 Di Jorio O., dz. cyt., s. 17. 
ważności i nowości. Argumenty te mają się odnosić nie do dekretu, który do sprawy nie wnosi wiele, ale do zwalczanego rekursem wyroku pierwszej instancji. Jeśli chodzi o terminy, wydaje się, że mają one charakter terminów zawitych, inaczej bowiem nie miałyby sensu ${ }^{166}$.

Ostatnia faza nowego procesu toczyć się więc może w trzeciej instancji i może się tam zakończyć albo stwierdzeniem zakończenia sprawy, albo umotywowanym dekretem, albo wyrokiem (n. IX, § 2).

Rozwój sytuacji jest $\mathrm{w}$ trzeciej instancji uzależniony od tego, kto składa rekurs, obrońca czy strona.

Stanowisko obrońcy węzła trzeciej instancji jest decydujące w stosunku do rekursu wniesionego przez obrońcę węzła drugiej instancji. W rzeczywistości sam obrońca trzeciej instancji decyduje; czy rekurs podtrzymać, czy nie. Ma wprawdzie obowiązek wysłuchać na ten temat zdania przewodniczącego trybunału, ale zdanie to nie jest dla niego wiążące. Jeśli nie podtrzyma rekursu, trybunałowi nie pozostaje nic innego, jak stwierdzić zakończenie procesu. Dekret w tej sprawie wydaje oficjał ${ }^{\mathbf{1 6 7}}$.

Gdyby obrońca rekurs podtrzymał, trybunał, w ciągu miesiąca od złożenia rekursu - tak samo jak wówczas, kiedy rekurs wniosła strona - albo wydaje dekret odrzucający rekurs, albo dekret dopuszczający sprawę do zwyczajnego rozpatrzenia w trzeciej instancji, która zakończy się wydaniem wyroku.

W tym ostatnim wypadku dzieje się rzecz dziwna. Dopuszczenie bowiem do rozpatrzenia sprawy drogą normalnego procesu w trzeciej instancji jest $\mathrm{w}$ rzeczywistości niczym innym, jak prawdziwą drugą instancją. Jest tak dlatego, że dekret drugiej instancji, zatwierdzający wyrok pierwszej, nie jest w rzeczy samej wyrokiem kończącym instancję sądową. Niewątpliwie ,dekret ten w jakiś sposób jest równoważny $\mathrm{z}$ wyrokiem, a skrócone postępowanie apelacyjne w sprawie stanowi równowartość drugiej instancji, z korzyścią dla trwania procesu, co zakłada zastąpienie dłuższej formy postępowania krótszą". To przeskoczenie instancji, względnie przeniesienie jej do trybunału trzeciego stopnia zdaje się być usprawiedliwione koniecznością pogodzenia mieszanego systemu orzekania przy pomocy wyroku i dekretu, który to system został przez MPCM przyjęty. Słusznie zauważa Ca breros de Anta, że tego typu druga instancja, prowadzona przez trybunał trzeciego stopnia jest jak gdyby złośliwą pułapką, którą całe ustawodawstwo MPCM, zmierzające do maksymalnego skrócenia procesu małżeńskiego w czasie, chciało ominąć ${ }^{168}$.

166 Di Jorio O., dz. cyt., s. 17.

167 Del Amo Pachon L., dz. cyt., s. 128.

168 Cabreros de Anta M., dz. cyt., s. 247-249. 
Należy jednak przypuszczać, że sprawy tego rodzaju będą należeć do rzadkości.

W praktyce, przy rozważaniu rekursu w trzeciej instancji, sędziowie będą musieli odpowiedzieć na wstępne pytanie, czy mianowicie ważne, nowe i będące już do dyspozycji trybunału dowody, zostały rzeczywiście przedstawione przez składającego rekurs. Dekret, którym trybunał trzeciej instancji odrzuca lub przyjmuje rekurs, ma być wydany w ciągu miesiąca od złożenia rekursu, co chyba należy rozumieć w ten sposób, że trybunał będzie tym terminem związany, o ile składający rekurs wraz z nim przedstawił nowe i ważne dowody ${ }^{169}$.

\section{ZASADY OBOWIĄZUJĄCE W WYPADKACH SPECJALNYCH}

X. Gdy na podstawie pewnego i autentycznego dokumentu, który wyklucza wszelki sprzeciw lub zarzut, ustali sie istnienie przeszkody powodujacej nieważność małżenstwa $i$ równocześnie z taka sama pewnościa okaże się, że od tych przeszkód nie udzielono dyspensy, wtedy pomijajac przepisany prawem zwyczajny sposób postępowania, będzie mógł Ordynariusz, wezwawszy strony orzec nieważność mał̇̇énstwa, przy udziale obrońcy węzła.

XI. Zachowujac $w$ mocy te same klauzule oraz ten sam sposób postepowania, o których była mowa w n. X, będzie mógł Ordynariusz orzec nieważność mał̇̇éstwa także wtedy, gdy zostanie wniesiona sprawa $z$ racji braku formy kanonicznej lub ważnego zlecenia dla petnomocnika.

XII. Jeśliby obrońca węzła był przekonany $w$ sposób uzasadniony, że istnienie przeszkód lub braków, o których mowa $w$ nn. X $i$ XI, nie jest pewne, albo prawdopodobnie była udzielona dyspensa, obowiazany jest odwołać się do sędziego drugiej instancji. Wtedy należy przesłać tam akta, a sędzia winien być pisemnie powiadomiony, że chodzi o wypadek specjalny.

XIII. Sędzia drugiej instancji orzeka - przy udziale obrońcy węzła - zachowujac sposób postępowania, o którym mowa wn. X czy wyrok należy zatwierdzić, czy raczej należałoby wszczać zwyczajne postępowanie sadowe. W tym ostatnim wypadku przesyła się sprawe do trybunału pierwszej instancji.

Skrócony sposób postępowania, zwany niegdyś sumarycznym, od początku swego istnienia, a więc od konstytucji apostolskiej pap. Klemensa V (1305-1314) Dispendiosam i Saepe contingit, w większym lub mniejszym stopniu obejmował sprawy małżeńskie.

169 Di Jorio O., dz. cyt., s. 18; Del Amo Pachon L., dz. cyt., s. 129. 
Kodeks Prawa Kanonicznego stał na stanowisku, że proces skrócony można zastosować tylko do ściśle określonych wypadków nieważności małżeństwa, spowodowanych przez przeszkody, których wyliczenie było taksatywne i o czym wyraźnie wypowiedziała się Papieska Komisja Interpretacyjna dnia 6 grudnia 1943 r. ${ }^{170}$.

Na liście tych przeszkód były następujące: węzeł małżeński, pokrewieństwo, powinowactwo, pokrewieństwo duchowe, wyższe święcenia, ślub uroczysty i różność wiary (kan, 1990).

Zasady postępowania $\mathrm{w}$ tych sprawach określał Kodeks w kan. 1990-1992 i Instrukcja Provida w art. 226-231.

MPCM w normach X-XIII wprowadza do tych przepisów zmiany.

Pierwsza $z$ nich dotyczy nazwy. To, co dotąd określano jako wypadki wyjęte (casus excepti), nazywa się obecnie wypadkami specjalnymi (casus speciales - por. tytuł tej części MPCM oraz n. XII).

Ale obok nowej nazwy MPCM zawiera jeszcze inne, bardziej istotne zmiany.

Norma X, jakkolwiek powtarza niemal dosłownie kan. 1990, różni się od niego tym, że zamiast wyliczać po kolei wszystkie przeszkody, które dają podstawę do prowadzenia procesu skróconego - jak to robił kan. 1990 - używa $\mathrm{w}$ to miejsce ogólnego określenia przeszkoda zrywająca (impedimentum dirimens).

Przedmiot procesu skróconegozostal w ten sposób znacznie poszerzony, gdyż w pojęciu przeszkody zrywającej mieszczą się nie tylko te przyczyny nieważności małżeństwa, które taksatywnie wyliczał Kodeks, ale i inne, nie objęte tym wykazem, a mianowicie: brak wieku (kan. 1607), impotencja (kan. 1608), uprowadzenie, kan. 1074), występek (kan. 1075), przeszkoda przyzwoitości publicznej (kan. 1078) i powinowactwa prawnego (kan. 1080).

Oprócz tego, n. XI MPCM pozwala na proces skrócony także wówczas, gdy sprawa prowadzona jest $z$ tytułu braku formy prawnej $\mathrm{lub}$ z braku ważnego pełnomocnictwa do zawarcia m a ż én s twa.

Nie wszyscy autorzy jednakowo tłumaczą te zmiany.

Najpierw jeśli chodzi o samą nazwę, Del A mo przez wypadki specjalne rozumie tylko te, które Ustawodawca dodał do wymienionych już w kan. 1990 171. Trudno jednak się z tym zgodzić. Określenie przeszkody zrywajace z natury swej obejmuje wszystkie przeszkody zawarte w kan. 1990172 , a ponadto MPCM używa nazwy wypadki specjalne

171 Del Amo Pachon L., dz. cyt., s. 131.

172 Gordon I., De m.p., s. 201. 
w tytule norm X-XIII, przez co wskazuje, że wszystkie wypadki w których prowadzi się proces skrócony, mieszczą się w tej nazwie.

Niektórzy autorzy uważają, że nie wszystkie przeszkody zrywające dają podstawę do prowadzenia procesu skróconego. Swoje zastrzeżenia w tym względzie uzasadniają tym, że MPCM traktuje iunctim przy tych procesach $i$ potrzebę dokumentalnego dowodu na istnienie przeszkody i potrzebę pewności, że od tej przeszkody nie została udzielona dyspensa, a więc pośrednio wskazuje na to, że te przeszkody, od których dyspensować nie można, nie uzasadniają procesu skróconego.

Z tych względów Di J orio uważa, że proces skrócony nie może mieć zastosowania przy przeszkodzie impotencji ${ }^{173}$, a Flatten wyklucza przeszkodę impotencji i uprowadzenia ${ }^{174}$.

Argumenty przeciwko tym twierdzeniom są jednak dość przejrzyste. I tak, przeciwko tym, którzy wymagają dokumentów na stwierdzenie przeszkody, można wskazać na autentyczną interpretację kan. 1990, wydaną dnia 16 czerwca 1931 r. przez Papieską Komisję Interpretacyjną, według której stwierdzenia takiego można dokonać nie tylko przy pomocy dokumentu, ale także ,alio legitimo modo" 175.

Przeciwko konieczności dyspensy można łatwo i mocno replikować tym, że i w kan. 1990 przeszkioda zrywająca węzła małżeńskiego nie podlega dyspensie, a przecież stosuje się do niej od dawna proces skrócony bez zastrzeżeń.

Procesu skróconego nie można jednak stosować przy stwierdzaniu nieważności małżeństwa, spowodowanej brakiem konsensu małżeńskiego, np. w wypadku pozornej zgody, przymusu czy amencji, wynika to nie tylko $\mathrm{z}$ faktu, że te przyczyny nieważności są przeszkodami w szerszym znaczeniu, ale też z tekstu samego MPCM, które w n. XI mówi o brakach zgody małżeńskiej, ale wprost zezwala przy nich na proces skrócony tylko w dwóch wypadkach: przy zaskarżeniu małżeństwa z braku formy prawnej i braku ważnego pełnomocnictwa ${ }^{176}$.

Proces skrócony można prowadzić $z$ tytułu braku formy prawnej niezależnie od tego, czy brak ten dotyczy formy zwyczajnej, czy nadzwyczajnej. W każdym jednakże wypadku małżeństwo musi być zawarte z zachowaniem jakiejś formy, inaczej bowiem mamy do czynienia po prostu z małżeństwem nieistniejącym. W takich okolicznościach, przed zawarciem nowego małżeństwa wystarczy przeprowadzić dochodzenie

173 Di Jorio O., dz. cyt., s. 19.

174 Flatten H., Dz. cyt., s. 20.

175 AAS 23 (1931) 353-354. Por. Gordon I., De m.p., s. 202-203; Di Jorio O., dz. cyt., s. 20, który, mimo znajamości tej odpowiedzi Komisji interpretacyjnej, wyklucza przeszkodę impotencji.

176 Lefebvre C.. Il motu proprio, s. 57; Bernardini E., dz. cyt., s. 78-79; Ferrata J. - Napoleoni H., dz. cyt., s. 26; Del Amo Pachon L., dz. cyt., s. 132; Gordon I., De m.p., s. 203. 
w sprawie stanu wolnego osób zainteresowanych (art. 231 Instrukcji Provida), bez uciekania się do trybunału ${ }^{\mathbf{1 7 7}}$.

Poza wskazanymi zmianami, MPCM pozostawia proces skrócony takim, jakim był w Kodeksie. Przeprowadza go ordynariusz miejsca lub oficjał na podstawie specjalnego mandatu ordynariusza, po wezwaniu stron i przy udziale obrońcy węzła małżeńskiego, ewentualnie rzecznika sprawiedliwości. Proces kończy się nie dekretem, lecz wyrokiem, od którego obrońca węzła nie ma ścisłego obowiązku apelować ${ }^{178}$.

MPCM weszło w życie $\mathrm{z}$ dniem 1 października $1971 \mathrm{r}$. Z oczywistych racji dokument ten został zaopatrzony w szereg zarządzeń, regulujących stopniowe wprowadzenie nowych norm do sądownictwa kościelnego. Ponieważ zarządzenia te miały charakter przejściowy, straciły już dziś swą aktualność i dlatego nie będą tutaj omawiane.

Ważne natomiast jest samo zakończenie dokumentu, w którym znajduje się klauzula derogacyjna: „,contrariis quibusvis, etiam specialissima mentione dignis, non obstantibus".

Klauzula ta, jak widać, cofa ważność wszelkiego istniejącego w ramach procesu małżeńskiego ustawodawstwa, jeśli sprzeciwia się ono przepisom zawartym w MPCM.

Ma to doniosłe znaczenie zwłaszcza dla tych terenów, które zaledwie co otrzymały szerokie przywileje $\mathrm{w}$ zakresie procesu małżeńskiego i już są zmuszone dostosować je do nowego, powszechnego prawodawstwa. Odnosi się to przede wszystkim do Stanów Zjednoczonych Ameryki Północnej i do Australii, normy bowiem wydane dla trybunałów tych krajów przez Stolicę Apostolską uległy w MPCM dość poważnej reformie.

\section{ZAKOŃCZENIE}

Motu proprio pap. Pawła VI Causas matrimoniales jest niewątpliwie bardzo poważnym krokiem w kierunku odnowy procesowego prawa małżeńskiego. $\mathrm{Z}$ całą pewnością nie jest to ostatnie słowo Ustawodawcy. Sporo spraw czeka jeszcze na rozwiązanie, by wspomnieć chociaż problem zdolności do zaskarżenia małżeństwa, doskonalsze określenie roli obrońcy węzła i adwokatów w procesie. Samo MPCM też nie jest wolne od pewnych niekonsekwencji. Ponieważ Papieska Komisja Rewizji Kodeksu Prawa Kanonicznego nie zakończyła swych prac, można się spodziewać dalszych zmian, które zaradzą niedomogom współczesnego sądownictwa kościelnego.

177 Di Jorio O., dz. cyt., s. 21; Cabreros de Anta M., dz. cyt., s. 250.

178 Cabreros de Anta M., dz. cyt.. s. 250. 


\section{DE PROCESSU MATRIMONIALI CANONICO IN MELIUS CORRIGENDO}

\section{A R G U M E N T U M}

Processus matrimonialis emendatio die 28 mensis Martii a. 1971 a SS. Paulo VI promulgata nullatenus dissolutionem vinculi matrimonialis faciliorem reddere intendit nec actualiter vigens substantivum matrimoniale ius aliquo modo convertere quaerit, sed tantum controversias matrimoniales expeditius vult dirimere nonnullas statuendo normas quibus pastoralis quoque Ecclesiae caritas planius evadere possit.

Auctor huius studii minime sibi proposuit, ut totum matrimonialem processum ab integro elaboraret, sed tantum nova elementa seu mutationes in luce ponere intendebat modo valorem earum efferens modo imperfectiones reprehendens. Quae nova processus matrimonialis elementa ad competentiam et compositionem tribunalis necnon ad appellationes et normas particulari casu servandas spectantia cum praecedenti legislatione canonica diligenter ab auctore conferuntur.

Illud pontificium documentum solum proprie et directe causas vinculi matrimonialis respicit eiusdem nempe vinculi validitatem.

Normae I - IV M. Pr. „Causas matrimoniales” de foro competenti pertractant. Forma canonica competentiae relativae seu territorialis tribunalis usque retinetur ratione habita loci in quo matrimonium est celebratum. Manet quoque, parum quidem mutata, secunda, quaestionem domicilii vel quasidomicilii attinens, forma, quae tamen verbis „commoratio non precaria" utitur certe non satis perspicuis. Nova inducta est forma competentiae relativae seu territorialis, tribunalis scilicet-loci in quo de facto colligi debent pleraeque depositiones seu probationes sub determinatis conditionibus. Alia gravis momenti immutatio in facultate consistit causam de alio ad aliud tribunal aeque competens transferendi si novae rerum circumstantiae hoc exigant habita locorum aut personarum ratione. Quae tamen facultas damno esse videtur generali principio processuali quod perpetuationem competentiae eius iudicis spectat qui primus reum citavit.

Normae V - VII de constitutione tribunalium peragunt. Tribunal unipersonale esse potest vel collegiale: trium nempe iudicum clericorum, non necessario sacerdotum ut in iure Codicis, vel duorum clericorum et unius viri laici, aut etiam unius tantum clerici in certis determinatis casibus. Munere assesoris et auditoris etiam viri laici fungi possunt, munus autem notarii gerere viris ac mulieribus, discrimine remoto, permittitur.

Norma praestantissima ad sistema appellationum pertinet, quod quidem multo brevius et expeditius nunc evadit semper tamen perplexum plus aequo remanens (normae VIII - IX).

Provincia processus iudicialis summarii in casibus particularibus latius nunc patet quod attinet ad huius processus obiectum-(normae $\mathrm{X}-\mathrm{XIII}$ ). 